\title{
Triggers and mechanisms of skeletal muscle wasting in chronic obstructive pulmonary disease.
}

Citation for published version (APA):

Langen, R. C. J., Gosker, H. R., Remels, A. H. V., \& Schols, A. M. W. J. (2013). Triggers and mechanisms of skeletal muscle wasting in chronic obstructive pulmonary disease. International Journal of Biochemistry \& Cell Biology, 45(10), 2245-2256. https://doi.org/10.1016/j.biocel.2013.06.015

Document status and date:

Published: 01/01/2013

DOI:

10.1016/j.biocel.2013.06.015

Document Version:

Publisher's PDF, also known as Version of record

Document license:

Taverne

Please check the document version of this publication:

- A submitted manuscript is the version of the article upon submission and before peer-review. There can be important differences between the submitted version and the official published version of record.

People interested in the research are advised to contact the author for the final version of the publication, or visit the DOI to the publisher's website.

- The final author version and the galley proof are versions of the publication after peer review.

- The final published version features the final layout of the paper including the volume, issue and page numbers.

Link to publication

\footnotetext{
General rights rights.

- You may freely distribute the URL identifying the publication in the public portal. please follow below link for the End User Agreement:

www.umlib.nl/taverne-license

Take down policy

If you believe that this document breaches copyright please contact us at:

repository@maastrichtuniversity.nl

providing details and we will investigate your claim.
}

Copyright and moral rights for the publications made accessible in the public portal are retained by the authors and/or other copyright owners and it is a condition of accessing publications that users recognise and abide by the legal requirements associated with these

- Users may download and print one copy of any publication from the public portal for the purpose of private study or research.

- You may not further distribute the material or use it for any profit-making activity or commercial gain

If the publication is distributed under the terms of Article $25 \mathrm{fa}$ of the Dutch Copyright Act, indicated by the "Taverne" license above, 
Review

\title{
Triggers and mechanisms of skeletal muscle wasting in chronic obstructive pulmonary disease ${ }^{\text {is }}$
}

\author{
R.C.J. Langen*, H.R. Gosker, A.H.V. Remels, A.M.W.J. Schols \\ NUTRIM School for Nutrition, Toxicology E' Metabolism, Department of Respiratory Medicine, Maastricht University Medical Center+, Maastricht, \\ The Netherlands
}

\section{A R T I C L E I N F O}

\section{Article history:}

Available online 1 July 2013

\section{Keywords:}

Muscle atrophy

Protein synthesis

Proteolysis

Myogenesis

\begin{abstract}
A B S T R A C T
Skeletal muscle wasting contributes to impaired exercise capacity, reduced health-related quality of life and is an independent determinant of mortality in chronic obstructive pulmonary disease. An imbalance between protein synthesis and myogenesis on the one hand, and muscle proteolysis and apoptosis on the other hand, has been proposed to underlie muscle wasting in this disease. In this review, the current understanding of the state and regulation of these processes governing muscle mass in this condition is presented. In addition, a conceptual mode of action of disease-related determinants of muscle wasting including disuse, hypoxemia, malnutrition, inflammation and glucocorticoids is provided by overlaying the available associative clinical data with causal evidence, mostly derived from experimental models. Significant progression has been made in understanding and managing muscle wasting in chronic obstructive pulmonary disease. Further examination of the time course of muscle wasting and specific disease phenotypes, as well as the application of systems biology and omics approaches in future research will allow the development of tailored strategies to prevent or reverse muscle wasting in chronic obstructive pulmonary disease.
\end{abstract}

This article is part of a Directed Issue entitled: Molecular basis of muscle wasting.

(c) 2013 Elsevier Ltd. All rights reserved.

\section{Contents}

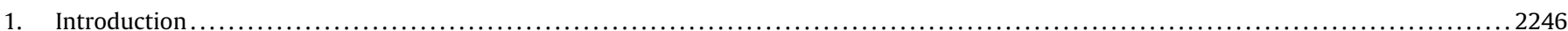

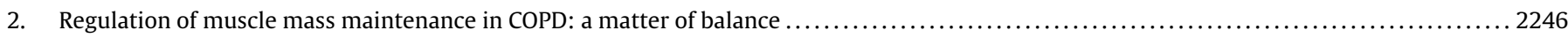

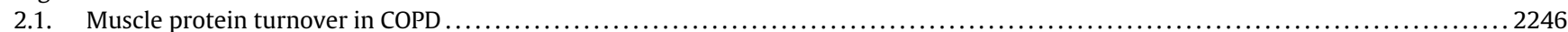

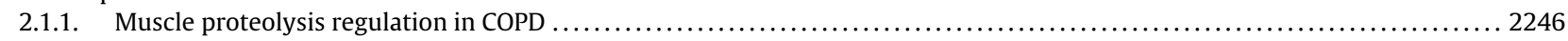

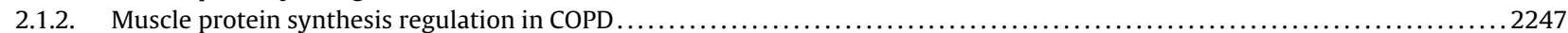

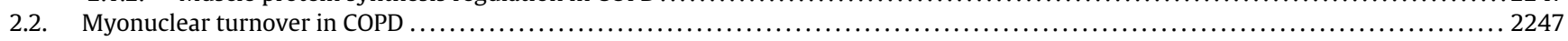

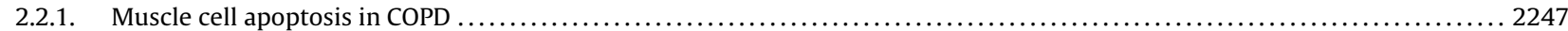

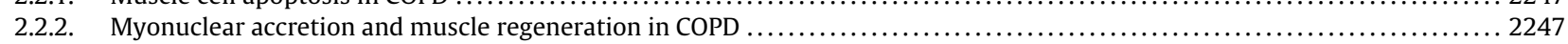

Abbreviations: 4E-BP1, 4E-binding protein-1; AA, amino acid; ALS, autophagy-lysosomal system; AMPK, adenosine monophosphate-activated protein kinase; COPD,

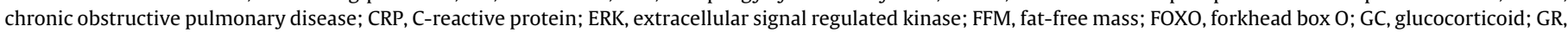

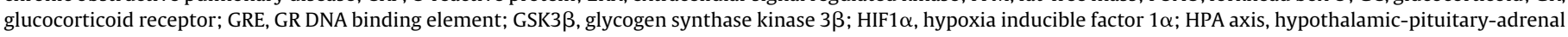

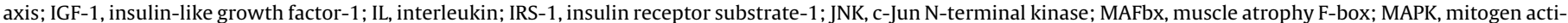

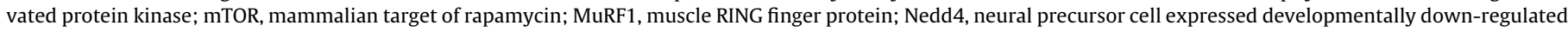

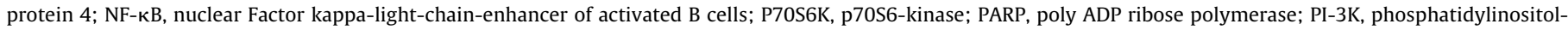

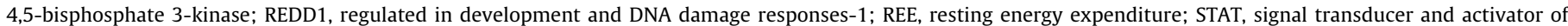

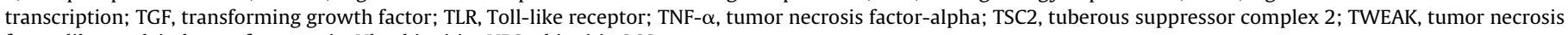
factor-like weak inducer of apoptosis; Ub, ubiquitin; UPS, ubiquitin 26S-proteasome system.

it This article is part of a Directed Issue entitled: Molecular basis of muscle wasting.

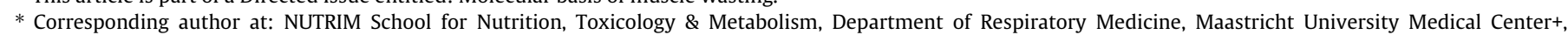
P.O. Box 5800, NL-6202 AZ Maastricht, The Netherlands. Tel.: +31 43 3884247; fax: +31 433875051.

E-mail addresses: r.langen@maastrichtuniversity.nl, a.schols@maastrichtuniversity.nl (R.C.J. Langen). 


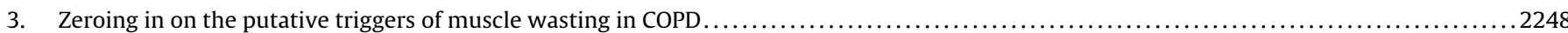

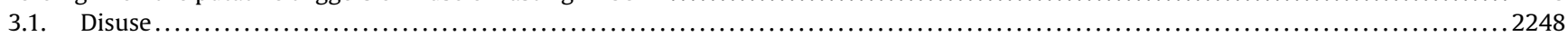

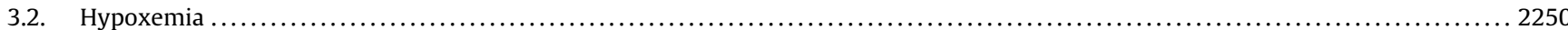

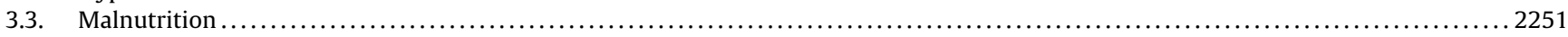

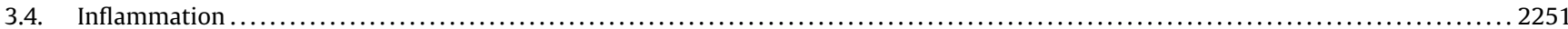

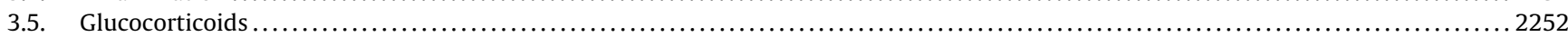

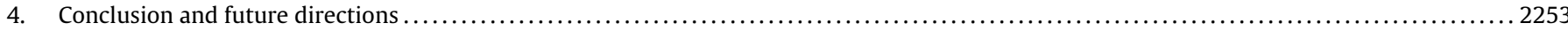

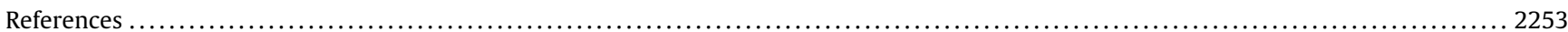

\section{Introduction}

Chronic obstructive pulmonary disease (COPD) is a lung disorder with progressive airflow obstruction resulting from inflammation and remodeling of the airways which often includes development of emphysema. Dominant symptoms are dyspnea and impaired exercise capacity adversely affecting health-related quality of life. COPD is characterized by episodes of acute worsening of symptoms referred to as exacerbations, which negatively affect disease progression (Tanabe et al., 2011) and survival (Soler-Cataluna et al., 2005). Although the lung is the primary diseased organ, COPD is increasingly acknowledged as a systemic disease due to its clinically significant extra-pulmonary consequences (Barnes and Celli, 2009). Systemic degenerative manifestations in COPD include osteoporosis (Romme et al., 2012) and muscle wasting. The prevalence of muscle atrophy is relatively high in COPD: 20-40\% depending on definition and disease stage (Engelen et al., 1994; Schols et al., 1993). Moreover, as body composition is not routinely assessed, the prevalence of muscle atrophy most likely is underestimated as selective depletion of fat-free mass (FFM) despite relative preservation of fat mass is seen in a substantial proportion of patients with normal body weight (Engelen et al., 1999). Importantly, muscle wasting not only contributes to diminished muscle function, reduced exercise capacity and decreased health status (Baarends et al., 1997a; Mostert et al., 2000), but is also a determinant of mortality in COPD independent of airflow obstruction (Schols et al., 2005; Vestbo et al., 2006). In addition to muscle mass depletion, a shift in muscle fiber composition from type I to type II, accompanied by a decrease in oxidative capacity culminates in reduced muscle endurance. This not only contributes to reduced exercise capacity (Gosker et al., 2002; Maltais et al., 2000), but may also accelerate muscle wasting in COPD (Remels et al., 2012) since type II fibers are generally more susceptible to atrophy stimuli (as reviewed elsewhere in this issue). Muscle atrophy in COPD has been demonstrated by decreases in FFM at whole body level, but also specifically at the level of the extremities (Bernard et al., 1998). In addition, muscle atrophy is apparent as a decrease in the size of individual muscle fibers, and this muscle fiber atrophy in COPD seems selective for type II fibers in peripheral muscle (Caron et al., 2009; Gosker et al., 2002).

The last two decades have yielded some insight in the impairments of the processes governing muscle mass, i.e. protein- and myonuclear turnover, and identified putative triggers of muscle wasting in COPD. The current knowledge on the processes that govern muscle mass in relation to muscle wasting in COPD is mostly derived from (immuno)histochemical and biochemical analyses of patient muscle biopsies, and described in the first part of this review. A number of factors that may result in muscle atrophy have been implicated as potential triggers of muscle wasting in COPD. These include disuse, hypoxemia, malnutrition, inflammation, and glucocorticoids. In the second part of this review, the associative evidence between these putative triggers and muscle wasting in COPD, as well as the data derived from experimental models supporting a causal contribution of these factors to muscle wasting will be presented.

\section{Regulation of muscle mass maintenance in COPD: a matter of balance}

Muscle mass is determined by the net balance of muscle protein synthesis and protein breakdown with at least a supportive role of the balance between myonuclear loss and -accretion determined by apoptosis of myofiber nuclei and recruitment of myonuclei from muscle progenitor cells including satellite cells.

\subsection{Muscle protein turnover in COPD}

It is currently unclear whether reduced muscle protein synthesis, increased proteolysis or both are responsible for muscle atrophy in COPD. Increased protein turnover on the whole body level has been reported in COPD (Engelen et al., 2000a; Kao et al., 2011). This could reflect activation of muscle protein synthesis as a compensatory adaptation to increased muscle proteolysis in an attempt to maintain muscle mass. However, when assessing whole body protein turnover, the contribution of different compartments has to be considered. For instance, pulmonary remodeling, myelopoiesis, and hepatic production of acute phase response proteins, are all energy-demanding processes involving increased protein synthesis, which may rely on amino acids (AA) provided by increased muscle proteolysis (Pereira et al., 2005). To illustrate this, when stratified for the presence of emphysema, which is characterized by active pulmonary remodeling, muscle leucine concentrations were decreased in emphysematous compared to non-emphysematous COPD patients (Engelen et al., 2000b).

\subsubsection{Muscle proteolysis regulation in COPD}

Whereas the studies in which muscle protein synthesis was measured are limited in COPD (Morrison et al., 1988), none exist on direct detection of muscle protein degradation rates. This is likely the consequence of technical challenges imposed by measuring muscle proteolysis; surrogate indices however have been reported in COPD. Whole body myofibrillar protein degradation was found to be increased in underweight patients compared to controls and normal-weight patients (Rutten et al., 2006). Additional indirect evidence for increased muscle proteolysis rate was shown in emphysematous and underweight COPD patients based on increased circulatory levels of 3-methylhistidine, which is a product of myofibrillar protein breakdown (Ubhi et al., 2011). Although our knowledge of muscle protein degradation and synthesis derived from direct muscle protein turnover measurements are limited in COPD, some insights can be distilled from studies in which the regulatory cues and pathways of these processes were investigated in muscle biopsies.

Several proteolytic systems in skeletal muscle appear to be involved in the degradation of myofibrillar proteins. The ubiquitin (Ub) 26S-proteasome system (UPS) is considered a rate-limiting proteolytic system involved in muscle atrophy. Protein degradation by the UPS relies on selective conjugation of Ub molecules to substrate protein by E3 Ub-ligases. These poly-Ub chains are subsequently recognized and degraded by the 26S-proteasome. Increased levels of $\mathrm{Ub}$ conjugation have been demonstrated in 
biopsy homogenates of COPD patients with muscle atrophy compared to controls (Fermoselle et al., 2012; Lemire et al., 2012). In particular, muscle-specific E3 Ub-ligases atrogin-1 (or MAFbx) and muscle-specific RING finger protein 1 (MuRF1) are essential for muscle atrophy under various conditions (Glass, 2005). In COPD, atrogin-1 mRNA and protein levels, not MuRF1, were found increased in peripheral muscle of muscle-atrophied COPD patients compared to controls (Lemire et al., 2012; Plant et al., 2010) while atrogin-1 mRNA and protein as well as MuRF1 mRNA and total protein ubiquitination were increased in cachectic (i.e. muscle atrophied and underweight) patients compared to controls (Doucet et al., 2007; Fermoselle et al., 2012). Moreover, muscle atrogin-1 protein content was specifically increased in cachectic COPD patients compared to non-cachectic patients (Vogiatzis et al.). An additional E3 Ub-ligase, neural precursor cell expressed developmentally down-regulated protein 4 (Nedd4), also displayed increased expression in muscle-atrophied patients with severe COPD compared to controls (Plant et al., 2010).

Atrogin-1 and MuRF1 are regulated by forkhead transcription factors FOXO-1 and -3 (Glass, 2005). Both FOXO-1 and FOXO-3 mRNA levels, as well as FOXO-1 nuclear content, were shown to be increased in peripheral muscle of cachectic and muscle-atrophied COPD patients compared to controls (Debigare et al., 2010; Doucet et al., 2007). In addition, regulation of MuRF1 expression by Nuclear Factor kappa-light-chain-enhancer of activated B cells (NF- $\kappa \mathrm{B})$ has been postulated (Cai et al., 2004), and evidence suggestive of NF-кB activation in atrophying muscle has been described in both underweight and cachectic COPD patients (Agusti et al., 2004; Vogiatzis et al., 2010). Recently, increased atrogin-1 protein expression in muscle-atrophied COPD patients was associated with elevated expression and activity of the mitogen activated protein kinases (MAPK) p38, ERK 1/2 and JNK, which inversely correlated with midthigh cross-sectional area (Lemire et al., 2012). However, others found no differences in MAPK expression or activation in muscle biopsies of COPD patients with muscle wasting (Fermoselle et al., 2012; Riddoch-Contreras et al., 2012). Of importance, conclusive evidence for a direct role of MAPKs in UPS-mediated proteolysis in conditions of muscle atrophy, as well as putative regulatory mechanisms of E3 Ub-ligase expression in COPD remain to be established.

\subsubsection{Muscle protein synthesis regulation in $C O P D$}

The insulin-like growth factor-1 (IGF-1)-Akt signaling cascade is an essential pathway in muscle maintenance and growth, as it suppresses muscle proteolysis and stimulates muscle anabolism and hypertrophy (Glass, 2005). Circulating IGF-1 levels were not altered in between mild, moderate and severe COPD patients when compared to controls (Piehl-Aulin et al., 2009), or in cachectic vs non-cachectic patients (Debigare et al., 2003). However, serum IGF-1 levels were decreased during an acute exacerbation (Crul et al., 2007; Kythreotis et al., 2009), an episode during which skeletal muscle wasting may be accelerated in COPD patients (Remels et al., 2012). Control of muscle IGF-1/Akt signaling and muscle plasticity responses have been attributed to locally produced IGF-1 (Shavlakadze et al., 2005). In line with this notion, decreased IGF-1 expression levels corresponded with decreased muscle mass in cachectic compared to non-cachectic COPD patients (Vogiatzis et al., 2010). Decreased IGF-1 expression was also reported in muscle biopsies obtained from patients hospitalized for an acute exacerbation (Crul et al., 2007). Nevertheless, in atrophied muscle of COPD patients with preserved fat mass increased rather than decreased muscle IGF-1 mRNA levels were observed, (Lewis et al., 2011). Interestingly, despite increased IGF-1 mRNA expression, Akt phosphorylation levels were not altered, suggesting impairments in the IGF-1/Akt signaling axis. Moreover, a counterintuitive raise in Akt activity levels reported in peripheral muscle of cachectic patients was accompanied by elevated rather than decreased atrogin-1 and MuRF1 expression levels (Doucet et al., 2007; Vogiatzis et al., 2010), which contrasts the postulated suppressive effects of Akt signaling on the expression of these E3 Ub-ligases (Glass, 2005). Intriguingly, increased phosphorylation of downstream mediators of mRNA translation, 4E-BP1 and P70S6K reflected increased Akt activity in atrophied skeletal muscle. These adaptations were interpreted as a futile cellular attempt to restore muscle mass in cachectic COPD muscle (Doucet et al., 2007). Of importance, some of the discrepant findings may relate to the heterogeneity of the studied populations with respect to body composition, COPD phenotype, severity and phase of the disease, e.g. during or following a disease exacerbation vs stable disease. In addition, incorporating assessment of muscle protein synthesis and degradation rates in combination with analyses of the regulatory pathways of protein turnover will allow to determine whether, and at which level of regulation, anabolic and anti-catabolic therapeutic strategies should be directed.

\subsection{Myonuclear turnover in COPD}

The concept of a 'myonuclear domain' (a given nucleus only controls a certain volume of cytoplasm) implies that a myofiber, upon loss or gain of volume, will have to adapt its nuclear content (Allen et al., 1999). Consequently, loss of muscle mass may not only rely on changes in protein metabolism, but may also involve changes in loss and accretion of myonuclei in muscle fibers. Although the exact mechanisms remain to be identified, loss of myonuclei is postulated to result from apoptotic events. Accretion of myonuclei on the other hand is the result of fusion of mononuclear myoblasts with adjacent myofibers. These cells arise from locally residing 'satellite cells', proliferate and subsequently differentiate under the influence of myogenic differentiation factors.

\subsubsection{Muscle cell apoptosis in COPD}

Literature regarding peripheral muscle cell apoptosis in COPD is limited and available studies report discrepant findings. Increased DNA fragmentation in myonuclei and PARP cleavage in homogenates of muscle biopsies of underweight COPD patients compared to normal-weight patients or healthy controls were suggestive of increased apoptosis (Agusti et al., 2002; Barreiro et al., 2011). Of three apoptotic markers, only myonuclear DNA fragmentation was consistently increased in muscle of patients with severe COPD but normal weight and body composition (Agusti et al., 2002; Barreiro et al., 2011). In contrast, in muscle-atrophied patients myonuclear DNA fragmentation and active caspase-3 levels as additional marker of apoptosis were not different compared to controls (Gosker et al., 2003). However, in this study, myofiber atrophy was accompanied by mild fibrosis and replacement of myofibers by adipocytes. Fibroblast and adipocyte replacement are myopathological features observed in muscular dystrophies, and considered a consequence of satellite cell depletion following continuous rounds of muscle regeneration.

\subsubsection{Myonuclear accretion and muscle regeneration in COPD}

Although satellite cell numbers are not decreased in normal weight COPD patients with (Eliason et al., 2009) or without (Menon et al., 2012) type II myofiber atrophy, satellite cell senescence has been reported in muscle biopsies of patients with severe COPD (Theriault et al., 2012). This is consistent with the notion of a decreased myogenic potential of skeletal muscle of COPD patients. However, satellite cell proliferation in response to an acute bout of resistance exercise was not different in patients with maintained muscle mass compared to healthy subjects (Menon et al., 2012).

Impaired muscle regeneration may contribute to muscle atrophy in COPD, as it inhibits myonuclear accretion of myofibers, limiting their capacity for (re)growth. In addition to satellite cell 
activation and proliferation, subsequent myogenic differentiation and myoblast fusion is essential for muscle regeneration. mRNA levels of myogenic differentiation factors Myf5, MyoD and myogenin were unaltered in peripheral muscle of muscle-atrophied COPD patients compared to controls (Plant et al., 2010). However, muscle myogenin expression was lower in cachectic patients compared to controls and MyoD protein levels were significantly decreased in cachectic $v s$ non-cachectic COPD patients (Fermoselle et al., 2012; Vogiatzis et al., 2010). In addition, patients experiencing an acute exacerbation displayed reduced muscular levels of MyoD mRNA and protein compared to healthy controls (Crul et al., 2007). Myostatin is expressed and secreted by skeletal muscle (Hittel et al., 2009) and is a member of the Transforming Growth Factor (TGF)-beta superfamily, which suppresses muscle growth by acting at multiple levels, including inhibition of satellite proliferation and myogenic differentiation (Kollias and McDermott, 2008). Circulatory myostatin levels were elevated in COPD patients compared to controls and correlated inversely with muscle mass (Ju and Chen, 2012). Myostatin mRNA expression in peripheral muscle was increased in muscle-atrophied COPD patients compared to controls (Plant et al., 2010) and inversely correlated with quadriceps strength in COPD patients (Man et al., 2010). Protein levels of myostatin however, were unchanged in muscle of cachectic vs non-cachectic patients (Vogiatzis et al., 2010). As no healthy controls were included in that study, it remains to be determined whether alterations in myostatin expression precede muscle atrophy in COPD.

Muscle regenerative capacity may be reflected by traininginduced myogenic responses. Normal-weight COPD patients and controls displayed similar training-induced increments in peak work rate and muscle expression of MyoD mRNA, MyoD protein and myogenin mRNA (Lewis et al., 2007; Vogiatzis et al., 2007). Moreover, a reduction in myostatin mRNA levels upon pulmonary rehabilitation in combination with testosterone supplementation was observed in normal-weight COPD patients (Lewis et al., 2007), indicating that muscle of COPD patients can mount a myogenic response upon training. Interestingly, rehabilitationinduced increases in MyoD mRNA occurred both in cachectic and non-cachectic patients, while MyoD protein only increased in non-cachectic patients (Vogiatzis et al., 2010). On a similar note, quadriceps myostatin mRNA and protein expression were reduced in non-cachectic and normal-weight patients, but not in cachectic COPD patients, upon resistance training or pulmonary rehabilitation respectively (Troosters et al., 2010; Vogiatzis et al., 2010). This was accompanied by a significant attenuation in myofiber size growth in the latter group, suggesting an impaired capacity for muscle regeneration and peripheral muscle mass recovery in response to exercise training in cachectic patients.

Although it remains to be addressed whether and to what extent alterations in myonuclear turnover determine changes in muscle mass, overall the studies discussed here suggest it may be impaired in atrophying muscle in COPD. Restoring myogenic responses may further improve effects of pulmonary rehabilitation on recovery of muscle mass in cachectic COPD patients.

\section{Zeroing in on the putative triggers of muscle wasting in COPD}

The apparent discrepancies between studies and heterogeneity in the underlying processes of muscle wasting in COPD may be attributable to the multitude of factors capable of inducing muscle atrophy. These factors may occur in isolation or in concert during different phases of the disease. Putative triggers of muscle wasting in COPD include disuse, hypoxemia, malnutrition, inflammation and endogenous as well as synthetic glucocorticoids. These may be a direct consequence of the decreased function and pathological remodeling of the diseased lung, e.g. hypoxemia and pulmonary inflammation, or may concern physiological and behavioral mal-adaptations, e.g. disuse and malnutrition. During disease exacerbations these factors converge and, together with synthetic glucocorticoids as a common medical intervention, may synergize to accelerate muscle wasting. Fig. 1 provides an overview of the pathways and processes affected by these triggers and how they may contribute to muscle wasting in COPD.

\subsection{Disuse}

A sedentary lifestyle is a common characteristic of COPD (Vorrink et al., 2011) and has profound effects on peripheral skeletal muscle mass and function. Already in mild COPD, physical inactivity was independently associated with quadriceps wasting (Shrikrishna et al., 2012). Moreover, disease exacerbations are accompanied by reduced levels of physical activity (Pitta et al. 2006). Inactivity was not only attributable to bed rest during hospitalization as a sustained reduction in physical activity level was still observed more than a month following discharge (Donaldson et al., 2005).

Inactivity, muscle disuse and unloading are well-documented triggers of muscle atrophy. These have been modeled in humans by limb immobilization or suspension, or by enforcing sustained bed rest, which is followed by significant muscle atrophy and reduced muscular strength (Murton and Greenhaff, 2010). Both decreased protein synthesis and increased proteolysis have been reported in skeletal muscle during disuse atrophy. However, in contrast to protein synthesis, the changes in proteolysis in disuse atrophy may be transient in nature. Increased ubiquitin conjugates and MuRF1 and atrogin-1 mRNA transcript levels were observed $48 \mathrm{~h}$ following initiation of limb immobilization in both young and aged healthy volunteers (Abadi et al., 2009; Glover et al., 2010; Suetta et al., 2012). In conjunction, elevated intramuscular interstitial levels of 3-methylhistidine were detected $72 \mathrm{~h}$ after initiation of a similar protocol (Tesch et al., 2008). In contrast, there is less evidence to support a sustained increase in proteolysis rates during sustained inactivity. Although the expression of some transcripts encoding UPS components, including atrogin-1 but not MuRF1, was increased 14 days following initiation of limb immobilization (Jones et al., 2004), these changes were not observed in similar studies. Moreover, MuRF1 and atrogin-1 levels were even decreased in healthy aged subjects compared to baseline (Abadi et al., 2009; Suetta et al., 2012). Similarly, atrogin-1 and MuRF1 expression levels were not increased following 24 days of bed rest (Brocca et al., 2012). This clearly differs from the reports describing increased expression levels of these E3 Ub-ligases in muscle wasting in stable COPD, indicating that these alterations are unlikely to result from sustained disuse. Conversely, increased expression of Nedd4 in atrophied COPD muscle (Plant et al., 2010) may be the consequence of muscle disuse, as this E3 Ub-ligase was reported to be selectively elevated in experimental models of inactivity or unloading-induced muscle atrophy (Koncarevic et al., 2007). However, the contribution of Nedd 4 to muscle wasting is currently unclear, as opposing results were reported regarding its requirement in disuse atrophy in experimental models (Koncarevic et al., 2007; Nagpal et al., 2012).

Atrogin-1 and MuRF1 are essential for inactivity- and unloadinginduced muscle atrophy (Bodine et al., 2001), and their rapid induction following disuse has been attributed to transcriptional regulation by NF-кB and FOXO (Cai et al., 2004; Senf et al., 2010; Wu et al., 2011). The underlying mechanism of NF- $\kappa B$ activation in disuse atrophy has not been clarified, but altered mechanical tension and subsequent oxidative stress have been implicated as potential triggers (Dodd et al., 2010; Powers et al., 2012). Oxidative stress (Fermoselle et al., 2012) and evidence of NF- $\mathrm{KB}$ 


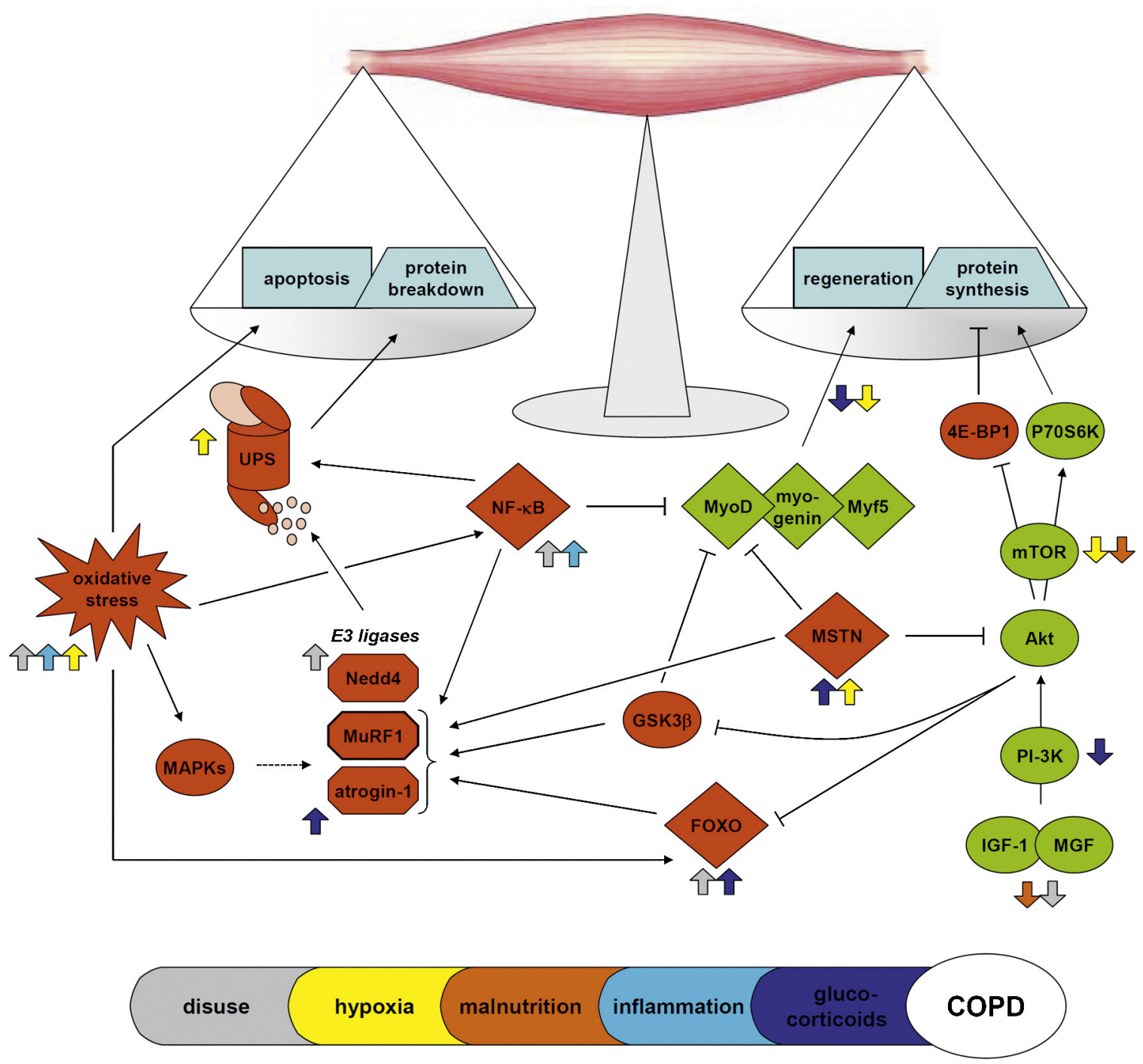

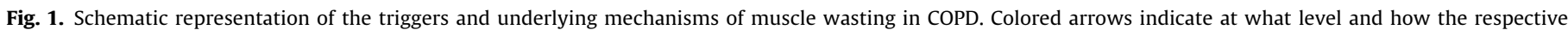

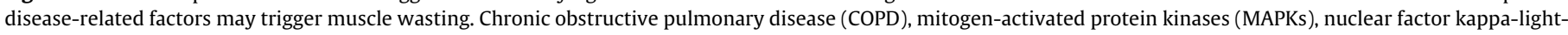

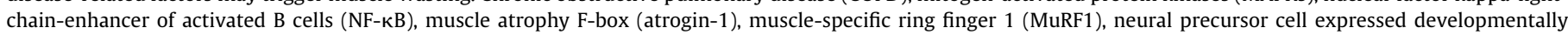

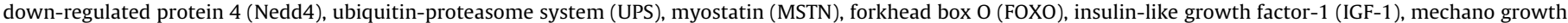

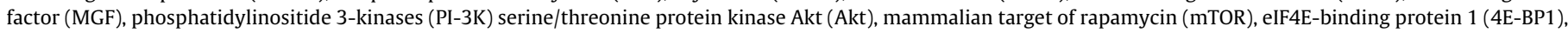
ribosomal protein S6 kinase (P70S6K), glycogen synthase kinase $3 \beta$ (GSK3 $\beta$ ).

activation have been demonstrated in muscle wasting in COPD, but it remains to be established whether they co-occur and are related to disuse. Although NF-кB signaling is required for inactivityand unloading atrophy (Cai et al., 2004; Van Gammeren et al., 2009), p50 and Bcl-3 have been identified as the constituents of the NF- $\kappa$ B complex responsible for transcriptional regulation of muscle atrophy in response to disuse (Wu et al., 2011). This may differ from immune response-associated canonical NF- $\kappa$ B signaling, which relies on the RelA-p50 hetero dimer. Activation of FOXO in response to disuse has been attributed to oxidative stress (Dodd et al., 2010). In addition, decreased IGF-1/Akt signaling also results in transcriptional activation of FOXO (Sandri et al., 2004). In atrophied muscle of COPD patients increased nuclear presence of FOXO has been described (Doucet et al., 2007), although this was accompanied by increased rather than decreased Akt phosphorylation, suggesting FOXO activation through non-canonical signaling routes. In addition, reduced IGF-1/Akt signaling will result in decreased mTOR/4E-BP1/p70S6K1 activity (Rommel et al., 2001) and subsequent inhibition of mRNA translation initiation, which lies at the basis of attenuated protein synthesis rates in disuse atrophy. However, whether this is applicable to COPD-associated muscle wasting remains to be determined, as indirect indices of protein synthesis signaling including Akt, 4E-BP1 and p70S6K1 phosphorylation were either unaltered (Plant et al., 2010) or even increased (Doucet et al., 2007), which is difficult to reconcile with decreased protein synthesis as observed in disuse atrophy.

Pulmonary rehabilitation is an intervention based on individually tailored exercise training and aims on improving exercise capacity and health status in COPD patients. In addition to improving endurance and fatigability, exercise training increases muscle strength, muscle mass, and muscle fiber size (Man et al., 2009). Although these effects of exercise training suggest a causal involvement of physical inactivity and disuse in muscle wasting, exercise training does not fully reverse all of the abnormalities observed in the peripheral muscle in COPD (Man et al., 2009). In cachectic COPD patients, exercise training-induced increases in myofiber size and muscle IGF-1 expression were significantly attenuated compared to non-cachectic COPD patients, which was accompanied by respectively down-regulation of myostatin and an induction of MyoD expression, only in non-cachectic patients (Vogiatzis 
et al., 2010). Moreover, up to one-third of the patients do not respond to pulmonary rehabilitation in terms of improved exercise capacity and muscle strength (Decramer, 2008). This suggests the presence of disease-related factors interfering with the effect of exercise training, or alternatively, the existence of triggers other than inactivity responsible for muscle wasting in this population of non-responding COPD patients. In addition, whereas inactivity correlated with muscle wasting in mild disease, these were not independently associated in more advanced COPD (Shrikrishna et al., 2012). Moreover, the specific type IIX fiber atrophy in COPD excludes a predominant involvement of physical inactivity, as disuse-induced reductions in muscle mass are characterized by type I muscle fiber atrophy (Hather et al., 1992). Altogether, this suggests that, although disuse may contribute to muscle atrophy associated with the milder stages of the disease and during hospitalization for acute disease exacerbations, additional factors besides inactivity drive muscle wasting in COPD.

\subsection{Hypoxemia}

Hypoxemia, i.e. reduced arterial oxygen tension, is an obvious consequence of respiratory failure, but surprisingly its potential impact on muscle maintenance in patients with COPD is rather unexplored. The prevalence of hypoxemia in COPD remains uncertain: although severe hypoxemia is estimated at $2 \%$ of the patient population (Tashkin et al., 2008), little data exist on the prevalence of intermittent, e.g. nocturnal and exertional hypoxemia. In addition, acute exacerbations are often accompanied by deterioration of pulmonary gas exchange, resulting in severe transient hypoxemia (Curtis and Hudson, 1994). Long-term oxygen treatment is accompanied by improvements in muscle function of hypoxemic COPD patients (Davidson et al., 1988), although reports assessing effects on muscle mass are lacking. Moreover, hypoxemia occurs more frequently in patients with emphysema compared to chronic bronchitis, with muscle wasting being more prevalent in the emphysematous subtype (Engelen et al., 1994).

Currently most of the evidence implying hypoxemia and subsequent tissue hypoxia as triggers of muscle wasting is derived from studies in healthy subjects and experimental models. Observations in mountaineering expeditions in which subjects were exposed to high altitude hypoxia reported decreased muscle mass (Hoppeler et al., 1990) and reduced muscle fiber size, regardless of physical activity levels (Mizuno et al., 2008). Similarly, simulated hypobaric hypoxia resulted in reductions in muscle mass and fiber crosssectional area (MacDougall et al., 1991). In humans as well as in animals exposed to hypoxia, reduced appetite and decreased food intake (hypophagia) have been described (Chaudhary et al., 2012; Favier et al., 2010; Westerterp-Plantenga et al., 1999). The expression of the satiety hormone leptin is controlled, in part, by the transcriptional regulator hypoxia inducible factor $1 \alpha$ (HIF1 $\alpha)$, and alterations in circulating leptin levels have been reported for cachectic COPD patients with more severe hypoxemia (Takabatake et al., 2001). Although these anorexic effects of hypoxia may contribute to muscle wasting as well, reductions in muscle mass independent of hypophagia have also been reported.

At the cellular level, adaptive responses to severe hypoxia include down-regulation of energy-consuming processes such as protein synthesis. Hypoxia suppresses protein synthesis at multiple levels, including inhibition of Mammalian target of rapamycin (mTOR) activity. This involves Regulated in development and DNA damage responses-1 (REDD1), as well as the sensor of cellular energy balance 5 -adenosine monophosphate-activated protein kinase (AMPK) (Liu et al., 2006; McGee and Hargreaves, 2010). Both REDD1 and AMPK inhibit mTORC1 through phosphorylation of the tuberous suppressor complex 2 (TSC2), which reinforces inhibition of mTORC1. Subsequent decreases in phosphorylation levels of p70S6K1 and 4E-BP1 result in reduced mRNA translation initiation and suppression of protein synthesis (Laplante and Sabatini, 2012). Most of these insights in the molecular control of protein synthesis by hypoxia stem from work related to tumor cell biology (Wouters and Koritzinsky, 2008). In those studies, predominantly severe hypoxic $\left(<1.5 \% \mathrm{O}_{2}\right)$ or even anoxic $\left(<0.02 \% \mathrm{O}_{2}\right)$ conditions were investigated, which may contribute to some discrepant findings of hypoxia in skeletal muscle described below. Muscle atrophy in rats subjected to hypoxia was accompanied by reduced mTOR, S6 but not 4E-BP1 phosphorylation, and this coincided with increased REDD1 expression (Favier et al., 2010). Interestingly, AMPK phosphorylation was reduced, illustrating decreased rather than elevated activity of this enzyme in response to chronic hypoxia in skeletal muscle. In this same study, the authors correlated decreased S6 phosphorylation in skeletal muscle of hypoxemic COPD patients with an increase (although non-significant) in a surrogate marker of REDD1 activity. Similarly, muscle REDD1 mRNA transcripts were increased in healthy subjects in response to $4 \mathrm{~h}$ of hypoxia, although this was accompanied by contradicting elevations in Akt and p70S6K1 phosphorylation levels (D'hulst et al., 2013). In line with this, increased muscle protein synthetic rates were detected in rats exposed to hypoxia. However, muscle mass still decreased regardless of increased protein synthesis, which was attributed to even greater elevations of muscle proteolysis (Chaudhary et al., 2012). Muscle atrophy in this study was accompanied by an elevation in Ub conjugates and UPSassociated proteolytic activity. Nevertheless, increased MuRF1 and atrogin-1 mRNA transcript levels have thus far only been reported in cardiac muscle in response to hypoxia (Razeghi et al., 2006). In addition, small increases in calpain- and lysosomal-associated proteolysis were detected following hypoxia in skeletal muscle. The latter may indicate the potential involvement of the autophagylysosomal system (ALS) in muscle proteolysis. This is of particular interest, as an increased autophagic flux is a well-characterized response of multiple cell types to hypoxia and essential for survival (Rouschop and Wouters, 2009). As studies addressing a contribution of autophagy to muscle atrophy associated with a variety of conditions are only recently emerging, its potential role in muscle alterations and wasting in COPD (Hussain and Sandri, 2012) will undoubtedly be scrutinized in due time.

Little information is available regarding the effects of hypoxia on myonuclear turnover. No evidence for in vivo myofiber apoptosis was observed following hypoxia (Riva et al., 2001). In addition, proliferative and myogenic potential of ex vivo cultured satellite cells was even improved under hypoxic conditions compared to culture in ambient oxygen levels, although hypoxia as applied here may rather reflect the physiological oxygen tension encountered by satellite cells in vivo (Urbani et al., 2012). Preferential stimulation of myoblast proliferation at the expense of myogenic differentiation in response to hypoxia has been reported, and was attributed to hypoxia-induced redirection of IGF-1/Akt to IGF-1/ERK signaling, in which Akt is controlled by oxygen levels independent of HIF1 $\alpha$ (Majmundar et al., 2012; Ren et al., 2010). Hypoxia may directly impair myogenesis by reducing MyoD protein stability, or indirectly by inducing myostatin expression as documented in skeletal muscles of hypoxemic COPD patients or rats exposed to chronic hypoxia (Di Carlo et al., 2004; Hayot et al., 2011). In addition, decreased regenerative potential of satellite cells obtained from skeletal muscle of hypobaric hypoxia exposed healthy subjects has been reported (Mancinelli et al., 2011).

A systems biology approach revealed an impaired muscle tissue remodeling response in COPD following an eight week training protocol (Turan et al., 2011). Although these COPD patients were not hypoxemic, network analyses revealed a set of aberrantly expressed oxygen-dependent histone modifiers, which have been implicated in tissue remodeling, including myogenesis. Reduced 
myogenic potential has also been suggested by decreased myogenin and MyoD expression in atrophied skeletal muscle of COPD patients, but clearly the causal involvement of hypoxia remains to be addressed (Fermoselle et al., 2012; Vogiatzis et al., 2010). Collectively, these studies indicate that tissue hypoxia undoubtedly affects muscle protein and myonuclear turnover. However, identification of the essential effectors and regulators of hypoxic responses involved in skeletal muscle plasticity and their molecular signatures will be required in order to elucidate the potential contribution of tissue hypoxia to muscle wasting in COPD.

\subsection{Malnutrition}

Malnutrition is reported in one-third of the COPD population, which may be severe with advanced disease (Ferreira et al., 2012). Malnutrition is the result of an imbalance between dietary energy intake and expenditure, and increased total energy expenditure has been reported in clinically stable COPD (Baarends et al., 1997b). In addition, reduced caloric intake is pronounced during COPD exacerbations, while accompanied by an increase in resting energy expenditure (REE) (Vermeeren et al., 1997). The energy imbalance and subsequent catabolic state as a consequence of anorexia and increased REE may result from increased circulating leptin levels, which have been reported in cachectic COPD patients and during acute exacerbations of the disease and appear to be related to hypoxemia and systemic inflammation (Creutzberg et al., 2000b; Schols et al., 1999; Takabatake et al., 2001).

Positive effects of nutritional supplementation suggest that loss of FFM in COPD may, to some extent, be attributable to malnutrition although for most subjects increasing energy intake alone did not improve skeletal muscle mass (Ferreira et al., 2012; Schols et al., 1995). A sub-population of COPD patients is characterized by preferential loss of skeletal muscle mass with relative preservation of fat mass (Schols et al., 2005). This contrasts physiological adaptations in response to fasting and starvation, which involve successive post-absorptive utilization of glycogen reserves and oxidation of fat, with relative sparing of muscle protein until the final stages of starvation. Of note, fasting is initially accompanied by a transient increase in muscle proteolysis (Goodman et al., 1984). The release of AA by skeletal muscle supports gluconeogenesis and serves as an energy source for other tissues and organs, and in response to fasting increased muscle proteolysis appears mainly the consequence of increased cortisol paralleled by decreased insulin levels (Wing and Goldberg, 1993). Subsequent reductions in muscle insulin/IGF-I receptor activation and signaling culminate in decreased Akt enzymatic activity, which affects cytosolic retention of FOXO (Stitt et al., 2004). The resulting nuclear translocation of FOXO drives the expression of key regulators of both UPS and ALS-mediated proteolysis. Although increases in nuclear FOXO abundance have been reported in skeletal muscles of COPD patients, this was in presence of unaltered or even increased rather than decreased Akt phosphorylation, suggesting that FOXO activation was unlikely to reflect starvation-induced muscle proteolysis regulatory cues (Doucet et al., 2007; Plant et al., 2010). Muscle protein synthesis decreases in response to starvation, and although one study reported a reduction of whole-body protein synthesis in underweight COPD patients (Morrison et al., 1988), later studies analyzing the regulatory pathways of protein synthesis in muscle tissue are not in support of reduced muscle protein synthetic rates: 4E-BP1 phosphorylation, a rate limiting step in mRNA translation, which decreases in response to starvation (Shah et al., 2000), was not affected or even increased in atrophied skeletal muscle of COPD patients (Doucet et al., 2007; Plant et al., 2010).

There is only limited data on effects of malnutrition on myonuclear turnover. Limited AA concentrations, and in particular inadequate branched chain AA availability inhibits myogenic differentiation (Averous et al., 2012; Haegens et al., 2012), and some evidence of suppressed myogenic activity has been reported in response to prolonged fasting (Jeanplong et al., 2003). Impaired myogenesis following AA deprivation may involve decreased MyoD expression, but also attenuated protein synthesis signaling. Interestingly, myostatin signaling conveys similar effects (McFarlane et al., 2011; Trendelenburg et al., 2009), but solid evidence implicating myostatin as a mediator of fasting-induced muscle atrophy is currently lacking.

Therefore, to clarify a potential contribution of malnutrition to muscle wasting in COPD, muscle protein turnover measurements with combined analyses of the signaling pathways that govern muscle protein metabolism and myogenesis should be incorporated in nutritional intervention studies conducted in malnourished COPD patients. In addition, it remains to be investigated whether the physiological adaptive responses to reduced caloric intake are intact in COPD, or whether these are aggravated by the interaction with other disease-related triggers of muscle wasting.

\subsection{Inflammation}

COPD is often associated with a chronic low-grade inflammatory state with increased circulating levels of tumor necrosis factoralpha (TNF- $\alpha$ ), soluble TNF- $\alpha$ receptors (sTNF-R), C-reactive protein (CRP) and interleukin (IL) $1 \beta$ and IL- 6 being reported (NussbaumerOchsner and Rabe, 2011). Elevated circulating levels of TNF- $\alpha$ and its soluble receptors have been associated with acute weight loss and reduced lean mass (Di Francia et al., 1994; Eid et al., 2001). Also, a more pronounced systemic inflammatory response to exercise was observed in cachectic patients compared to non-cachectic patients (van Helvoort et al., 2006). Whether systemic inflammation is the result of spill-over from inflammatory processes in the diseased lung remains to be resolved, as pulmonary and circulating levels of inflammatory mediators did not correlate (Vernooy et al., 2002), suggesting a potential contribution of other sources including circulating leukocytes or adipose tissue (Oudijk et al., 2005; van den Borst et al., 2012). Interestingly, increased serum levels of TNF- $\alpha$ and its soluble receptors were associated with hypoxemia in underweight COPD patients (Takabatake et al., 2000). In experimental models of chronic smoke exposure- or pulmonary inflammation-induced emphysema, moderate to severe muscle wasting was associated with systemic inflammation, including raised serum levels of TNF- $\alpha$ and its receptors (De Paepe et al., 2008; Gosker et al., 2009; Langen et al., 2006; Tang et al., 2010b).

Systemic inflammation, and in particular increased circulating TNF- $\alpha$ levels, has been implicated in various conditions accompanied by muscle atrophy (Moldawer et al., 1983; Tracey et al., 1988). Pro-inflammatory cytokines may induce muscle catabolism via a relay based on hypothalamic-pituitary-adrenal (HPA) axis activation, and subsequent glucocorticoid release (as will be discussed below) and proteolysis signaling in skeletal muscle (Braun et al., 2011). Nevertheless, exposure of cultured myotubes to TNF$\alpha$ alone or a cocktail of pro-inflammatory cytokines implicated a cell autonomous response in inflammation-induced muscle atrophy, mediated by NF- $\kappa$ B activation (Guttridge et al., 2000; Li and Reid, 2000). Constitutive activation of canonical NF- $\kappa$ B signaling in skeletal muscle caused muscle atrophy in mice, providing further support of an important role of NF- $\kappa \mathrm{B}$ in muscle mass regulation (Cai et al., 2004). Contradicting findings on NF-кB activity status in muscle biopsies of COPD patients have been reported (Agusti et al., 2004; Mercken et al., 2011; Plant et al., 2010). These inconsistent alterations in muscle NF- $\mathrm{KB}$ activity levels in COPD patients compared to controls may reflect differences in phases of the disease accompanied by decreased but stable muscle mass vs active muscle loss. The latter likely occurs during COPD exacerbations, 
considering the activation of the UPS reported in these episodes of the disease (Crul et al., 2010).

Indeed, pulmonary and systemic inflammation was more pronounced during acute exacerbations (Oudijk et al., 2006; Wouters et al., 2007). In addition, induction of acute pulmonary inflammation in animal studies is sufficient to trigger muscle atrophy, which was accompanied by systemic inflammation and muscle NF- $\mathrm{B}$ activation (Files et al., 2012; Langen et al., 2012). Genetic inhibition of muscle NF- $\kappa$ B activity markedly blunted the induction of MuRF1 expression, and genetic suppression of MuRF1 expression attenuated muscle atrophy. This suggests that increased UPS-mediated proteolysis is responsible for NF- $\mathrm{KB}$-dependent muscle atrophy following acute pulmonary inflammation. In line with that notion, elevated NF- $\kappa \mathrm{B}$ activation correlated with total muscle protein ubiquitination in quadriceps muscle of cachectic COPD patients (Fermoselle et al., 2012). Additional inflammatory mediators and signaling pathways, including TWEAK (Dogra et al., 2007), IL-17 and TLR-4 (Doyle et al., 2011; Tang et al., 2010a), and IL-6/STAT3 (Bonetto et al., 2011) have been implicated in inflammationassociated muscle proteolysis, but their presence and activation remains to be addressed in COPD-associated muscle wasting. In addition to enhancing proteolysis, inflammatory mediators may contribute to muscle atrophy through inhibition of protein synthesis (Williamson et al., 2005).

An inappropriate or unresolved inflammatory response may also cause suppression of myogenesis and impaired muscle regenerative potential. Studies in support of this latter notion revealed inhibition of muscle differentiation and regeneration upon TNF- $\alpha$ administration, which involved NF- $\mathrm{BB}$ dependent suppression of MyoD mRNA and MyoD protein destabilization (Guttridge et al., 2000; Langen et al., 2004). Interestingly, impaired muscle mass recovery in response to training was noted in cachectic COPD patients, which was accompanied by decreased MyoD expression and evidence of elevated NF- $\kappa$ B activity (Vogiatzis et al., 2010). Moreover, an impaired muscle regenerative response during recovery from disuse atrophy was also observed in emphysematous mice with systemic inflammation (Langen et al., 2006). Although the causal interference of inflammation with muscle mass recovery requires further investigation, it is interesting to draw a parallel with a study in which COPD patients who failed to gain weight in response to pulmonary rehabilitation, were characterized by elevated circulating levels of inflammatory mediators (Creutzberg et al., 2000a).

\subsection{Glucocorticoids}

As mentioned earlier, endogenous glucocorticoids (GCs) are required for muscle proteolysis associated with starvation and may contribute to inflammation-associated muscle atrophy. Synthetic, exogenously administered corticosteroids represent an additional modus by which GCs constitute a putative trigger of muscle atrophy relevant to COPD-associated muscle wasting. GCs are frequently applied during acute exacerbations for their anti-inflammatory properties and are sometimes used as maintenance treatment during end-stage disease. The efficacy of GCs as maintenance medication is controversial (Vestbo et al., 2013), and its use is associated with a dose-dependent increase in mortality risk in severe disease (Schols et al., 2001). Moreover, the use of GCs may affect skeletal muscle force and correlates with a decline in FFM independently of disease severity (Decramer et al., 1996; Hopkinson et al., 2007).

GCs and IGF-I signaling have opposing effects on muscle mass maintenance, and the molecular basis of their antagonistic effects has been clarified to some extent. Muscle IGF-I expression is suppressed by GCs (Schakman et al., 2008), whereas over-expression of muscle IGF-I prevents GC-induced muscle atrophy (Gilson et al., 2007; Schakman et al., 2005). Reduced IGF-I expression levels have been reported in muscle of patients during an exacerbation who were receiving oral corticosteroids (Crul et al., 2007).

GC signaling directly affects muscle protein turnover, which involves 'genomic and non-genomic' actions of activated GC receptor (GR). In this context, the best described non-genomic effects of GR activation rely on impairment of IGF/Akt signaling by interference of IRS-1-PI-3K association by GR (Hu et al., 2009). This was postulated to result in subsequent derepression of FOXO and suppression of mTOR activity consequent to decreased Akt signaling, which coordinately increases proteolysis and decreases protein synthesis. Conversely, genomic effects of GR activation related to protein turn over include impairments of IGF-I signaling upand downstream of Akt. GCs increase expression of the inhibitory P85 $\alpha$ subunit of the PI-3K complex, which requires GR-dependent transcriptional activation of P85 $\alpha$ and result in suppression of Akt activity (Kuo et al., 2012). GR-dependent transcription of REDD1 impinges mTOR activity, further reinforcing GC-mediated inhibition of IGF-1 expression and signaling downstream of Akt, and a subsequent reduction of protein synthesis (Kumari et al., 2011). In addition, FOXO transcription is increased by GR activation and this de novo expressed FOXO may override Akt-mediated nuclear exclusion resulting in increased FOXO-mediated atrogin-1 and MuRF1 expression (Shimizu et al., 2011). Moreover, increased expression of these atrogenes in response to GCs is dependent on GSK3 $\beta$, providing another level of IGF-1-GC cross-talk downstream of Akt (Schakman et al., 2008; Verhees et al., 2011). Myostatin expression is induced by GC signaling in skeletal muscle, and GC-induced muscle atrophy and proteolytic signaling is prevented in absence of myostatin (Gilson et al., 2007). As glucocorticoids are often administered during an acute exacerbation, increased myostatin expression could be anticipated in skeletal muscle of patients during COPD exacerbations, but currently no reports have assessed this. Increased myostatin expression has been reported in muscle of cachectic COPD patients with stable disease (Fermoselle et al., 2012).

GR DNA binding elements (GREs) have been identified in the promoter regions of the MuRF1 and myostatin genes, which in case of MuRF1 are required for full transactivation by GCs (Du et al., 2005; Waddell et al., 2008). Although MuRF1 and myostatin mRNA levels are elevated in atrophying COPD muscle, the contribution of relevant triggers other than GCs can not be ruled out as transcriptional regulatory elements in addition to GREs have been described in enhancer regions of these genes. In contrast, REDD1 expression has been postulated as a surrogate marker for muscle GR signaling (Kumari et al., 2011). Consequently, increased REDD1 expression observed in muscle of acutely hypoxemic COPD patients and hypoxia-exposed animals (Favier et al., 2010) may reflect increased cortisol or corticosterone levels that accompany hypoxemia (Chen et al., 2007; Raff and Levy, 1986).

GC signaling may also exert regulatory cues on muscle mass by affecting myonuclear turnover. Some evidence of myofiber apoptosis has been described in GC-induced myopathy (reviewed in (Dirks-Naylor and Griffiths, 2009)). Conversely, GC-mediated inhibition of myogenesis may impair myonuclear accretion, which not only interferes with muscle maintenance but also recovery of muscle mass (Pansters et al., 2012; Qin et al., 2010). Indeed, a gain in lean mass typically observed in response to pulmonary rehabilitation was absent in COPD patients using GCs (Creutzberg et al., 2003; Pansters et al., 2012).

A more comprehensive analysis of GR-dependent gene expression and non-genomic GR actions in skeletal muscle of COPD patients during stable disease and acute exacerbations will contribute to elucidating the potential contribution of GCs and increased GC signaling to muscle wasting in COPD. 


\section{Conclusion and future directions}

Although our insights in the pathobiology of muscle wasting in COPD has significantly improved the last two decades, contradicting findings in alterations of the processes that govern muscle mass complicate the formulation of targeted intervention strategies. Some of the discrepancies may result from confounding effects of co-morbidities or the uncontrolled use of drugs that possibly affect muscle anabolism, like long-acting beta- 2 agonists (MacLennan and Edwards, 1989). It is, however, essential to realize that apparent inconsistencies may be attributable to an intrinsic heterogeneity between COPD patients. These may in particular concern differences in (vulnerable) COPD sub-populations, e.g. cachectic emphysematous patients and relative obese patients with muscle atrophy (sarcopenic obesity), with specific characteristics that may impair muscle mass maintenance, such as hypoxemia or an altered adipose secretome. Systems biology and signaling pathway analyses approaches based on transcriptomic, proteomic and metabolomic assessments of muscle biopsies are a promising venue to identify divergent processes of muscle mass regulation in atrophying muscle in COPD based on coherent molecular signatures rather than single markers. In addition, pathway analyses approaches applied to muscle biopsy material may also prove extremely useful in identifying the disease-related triggers of muscle wasting.

COPD muscle wasting may involve a non-continuous reduction rather than a gradual decrease of muscle mass. Therefore the time-course of muscle wasting requires to be defined at higher resolution, as muscle atrophy may accelerate during exacerbations, while subsequent periods of clinically stable disease are characterized by impaired recovery of muscle mass. Such a biphasic course of muscle wasting is likely governed by separate processes, as acute exacerbations may involve muscle mass loss resulting from increased proteolysis, whereas sustained muscle atrophy may not recover during stable disease as a consequence of impaired responsiveness to signaling cues of muscle regeneration and protein synthesis. To address this potential differential involvement of processes that govern muscle mass in the distinct phases of muscle wasting in COPD, longitudinal studies to assess the course of muscle wasting in COPD should be combined with measurements of muscle protein turnover and supplemented with measures of satellite cell activity and myonuclear accretion. Of note, collecting biopsies of patients solely in static, resting conditions may not suffice: the concept that impaired responsiveness to anabolic stimuli compromises muscle mass recovery in COPD patients with stable disease and muscle atrophy could for instance be addressed by evaluating the ability of skeletal muscle to mount an appropriate protein synthetic response or satellite cell activation following an acute bout of exercise (Menon et al., 2012; Snijders et al., 2012; Witard et al., 2009).

A non-gradual course of muscle atrophy also has ramifications for the selection of experimental models appropriately reflecting the pathobiology of COPD-associated muscle wasting. Traditionally, chronic smoke exposure- or elastase instillation-induced emphysema in rodent models has been adopted to study cellular and molecular changes in skeletal muscle (Gosker et al., 2009; Mattson et al., 2004). However, the experimental models may require further refinement in order to more truthfully recapitulate the processes underlying COPD (Stevenson and Birrell, 2011) and in particular COPD-associated muscle wasting. For instance, in order to model exacerbation-associated alterations in skeletal muscle mass, a chronic smoke exposure model is not appropriate, but may require the addition of an infectious component or hypoxemic conditions, to more closely mimic the pulmonary changes associated with COPD exacerbation. Such an effort, deployed in combination with genetically modified mice, is essential in order to address the causal involvement of signaling molecules including NF-кB, FOXO, HIF1 and GR, that may relay muscle atrophy cues initiated by the suspected triggers of COPD muscle wasting, e.g. disuse, malnutrition, hypoxia, inflammation and glucocorticoids. Although it may prove a challenge, experimental modeling of COPD exacerbationassociated loss of muscle mass will be of particular interest, as multiple triggers of muscle atrophy do converge, which may activate synergistic and parallel signaling routes that determine muscle wasting.

Whereas these approaches are designed to identify specific triggers and their subsequent signaling routes to specifically target COPD-associated muscle wasting, the efficacy of therapeutic strategies deploying anabolic pharmacological agents aimed at restoring the (sub)cellular balance in protein and myonuclear turnover is relatively underexplored in COPD. Transient recovery of muscle mass by anabolic steroids has been reported (Casaburi et al., 2004), which, surprisingly, may synergistically interact with GCs to more potently stimulate myogenesis and muscle growth in COPD (Pansters et al., 2012). This further illustrates the necessity for experimental models with improved relevance for COPDassociated muscle wasting, as it will allow more robust pre-clinical evaluation of newly developed anabolic agents, including selective androgen receptor modulators and myostatin inhibitors, while screening for unanticipated effects resulting from the unique pallet of atrophy-inducing triggers in COPD muscle wasting.

In conclusion, significant progression has been made in understanding muscle wasting in COPD. Further examination of the time-course of muscle wasting and potential differences in patient sub-populations, as well as the application of systems biology and omics approaches in future studies is required for the development of more tailored single or multimodal strategies to prevent or reverse muscle wasting in COPD.

\section{References}

Abadi A, Glover EI, Isfort RJ, Raha S, Safdar A, Yasuda N, et al. Limb immobilization induces a coordinate down-regulation of mitochondrial and other metabolic pathways in men and women. PLOS ONE 2009;4:e6518.

Agusti A, Morla M, Sauleda J, Saus C, Busquets X. NF-kappaB activation and iNOS upregulation in skeletal muscle of patients with COPD and low body weight. Thorax 2004;59:483-7.

Agusti AG, Sauleda J, Miralles C, Gomez C, Togores B, Sala E, et al. Skeletal muscle apoptosis and weight loss in chronic obstructive pulmonary disease. American Journal of Respiratory and Critical Care Medicine 2002;166:485-9.

Allen DL, Roy RR, Edgerton VR. Myonuclear domains in muscle adaptation and disease. Muscle and Nerve 1999;22:1350-60.

Averous J, Gabillard JC, Seiliez I, Dardevet D. Leucine limitation regulates myf5 and myoD expression and inhibits myoblast differentiation. Experimental Cell Research 2012;318:217-27.

Baarends EM, Schols AM, Mostert R, Wouters EF. Peak exercise response in relation to tissue depletion in patients with chronic obstructive pulmonary disease. European Respiratory Journal 1997a;10:2807-13.

Baarends EM, Schols AM, Pannemans DL, Westerterp KR, Wouters EF. Total free living energy expenditure in patients with severe chronic obstructive pulmonary disease. American Journal of Respiratory and Critical Care Medicine 1997b;155:549-54.

Barnes PJ, Celli BR. Systemic manifestations and comorbidities of COPD. European Respiratory Journal 2009;33:1165-85.

Barreiro E, Ferrer D, Sanchez F, Minguella J, Marin-Corral J, Martinez-Llorens J, et al. Inflammatory cells and apoptosis in respiratory and limb muscles of patients with COPD. Journal of Applied Physics 2011;111:808-17.

Bernard S, LeBlanc P, Whittom F, Carrier G, Jobin J, Belleau R, et al. Peripheral muscle weakness in patients with chronic obstructive pulmonary disease. American Journal of Respiratory and Critical Care Medicine 1998;158: 629-34.

Bodine SC, Latres E, Baumhueter S, Lai VK, Nunez L, Clarke BA, et al. Identification of ubiquitin ligases required for skeletal muscle atrophy. Science 2001;294:1704-8.

Bonetto A, Aydogdu T, Kunzevitzky N, Guttridge DC, Khuri S, Koniaris LG, et al. STAT3 activation in skeletal muscle links muscle wasting and the acute phase response in cancer cachexia. PLOS ONE 2011;6:e22538.

Braun TP, Zhu X, Szumowski M, Scott GD, Grossberg AJ, Levasseur PR, et al. Central nervous system inflammation induces muscle atrophy via activation of the hypothalamic-pituitary-adrenal axis. Journal of Experimental Medicine 2011;208:2449-63. 
Brocca L, Cannavino J, Coletto L, Biolo G, Sandri M, Bottinelli R, et al. The time course of the adaptations of human muscle proteome to bed rest and the underlying mechanisms. Journal of Physiology 2012;590:5211-30.

Cai D, Frantz JD, Tawa NE Jr, Melendez PA, Oh BC, Lidov HG, et al. IKKbeta/NF-kappaB activation causes severe muscle wasting in mice. Cell 2004;119:285-98.

Caron MA, Debigare R, Dekhuijzen PN, Maltais F. Comparative assessment of the quadriceps and the diaphragm in patients with COPD. Journal of Applied Physics 2009;107:952-61.

Casaburi R, Bhasin S, Cosentino L, Porszasz J, Somfay A, Lewis MI, et al. Effects of testosterone and resistance training in men with chronic obstructive pulmonary disease. American Journal of Respiratory and Critical Care Medicine 2004; 170:870-8.

Chaudhary P, Suryakumar G, Prasad R, Singh SN, Ali S, Ilavazhagan G. Chronic hypobaric hypoxia mediated skeletal muscle atrophy: role of ubiquitin-proteasome pathway and calpains. Molecular and Cellular Biochemistry 2012;364: $101-13$.

Chen XQ Dong J, Niu CY, Fan JM, Du JZ. Effects of hypoxia on glucose, insulin, glucagon, and modulation by corticotropin-releasing factor receptor type 1 in the rat. Endocrinology 2007;148:3271-8.

Creutzberg EC, Schols AM, Weling-Scheepers CA, Buurman WA, Wouters EF. Characterization of nonresponse to high caloric oral nutritional therapy in depleted patients with chronic obstructive pulmonary disease. American Journal of Respiratory and Critical Care Medicine 2000a;161:745-52.

Creutzberg EC, Wouters EF, Mostert R, Weling-Scheepers CA, Schols AM. Efficacy of nutritional supplementation therapy in depleted patients with chronic obstructive pulmonary disease. Nutrition 2003;19:120-7.

Creutzberg EC, Wouters EF, Vanderhoven-Augustin IM, Dentener MA, Schols AM. Disturbances in leptin metabolism are related to energy imbalance during acute exacerbations of chronic obstructive pulmonary disease. American Journal of Respiratory and Critical Care Medicine 2000b;162:1239-45.

Crul T, Spruit MA, Gayan-Ramirez G, Quarck R, Gosselink R, Troosters T, et al. Markers of inflammation and disuse in vastus lateralis of chronic obstructive pulmonary disease patients. European Journal of Clinical Investigation 2007;37: 897-904.

Crul T, Testelmans D, Spruit MA, Troosters T, Gosselink R, Geeraerts I, et al. Gene expression profiling in vastus lateralis muscle during an acute exacerbation of COPD. Cellular Physiology and Biochemistry 2010;25:491-500.

Curtis JR, Hudson LD. Emergent assessment and management of acute respiratory failure in COPD. Clinics in Chest Medicine 1994:15:481-500.

D’Hulst G, Jamart C, Van Thienen R, Hespel P, Francaux M, Deldicque L. Effect of acute environmental hypoxia on protein metabolism in human skeletal muscle. Acta Physiologica Scandinavica 2013;208:251-64.

Davidson AC, Leach R, George RJ, Geddes DM. Supplemental oxygen and exercise ability in chronic obstructive airways disease. Thorax 1988;43:965-71.

De Paepe B, Brusselle GG, Maes T, Creus KK, D'Hose S, D'Haese N, et al. TNF alpha receptor genotype influences smoking-induced muscle-fibre-type shift and atrophy in mice. Acta Neuropathologica 2008;115:675-81.

Debigare R, Cote $\mathrm{CH}$, Maltais F. Ubiquitination and proteolysis in limb and respiratory muscles of patients with chronic obstructive pulmonary disease. Proceedings of the American Thoracic Society 2010;7:84-90.

Debigare R, Marquis K, Cote CH, Tremblay RR, Michaud A, LeBlanc P, et al. Catabolic/anabolic balance and muscle wasting in patients with COPD. Chest 2003;124:83-9.

Decramer M. Pulmonary rehabilitation 2007: from bench to practice and back. Clinical and Investigative Medicine Medecine Clinique et Experimentale 2008;31:E312-8.

Decramer M, de Bock V, Dom R. Functional and histologic picture of steroid-induced myopathy in chronic obstructive pulmonary disease. American Journal of Respiratory and Critical Care Medicine 1996;153:1958-64

Di Carlo A, De Mori R, Martelli F, Pompilio G, Capogrossi MC, Germani A. Hypoxia inhibits myogenic differentiation through accelerated MyoD degradation. Journal of Biological Chemistry 2004;279:16332-8.

Di Francia M, Barbier D, Mege JL, Orehek J. Tumor necrosis factor-alpha levels and weight loss in chronic obstructive pulmonary disease. American Journal of Respiratory and Critical Care Medicine 1994;150:1453-5.

Dirks-Naylor AJ, Griffiths CL. Glucocorticoid-induced apoptosis and cellular mechanisms of myopathy. Journal of Steroid Biochemistry and Molecular Biology 2009;117:1-7

Dodd SL, Gagnon BJ, Senf SM, Hain BA, Judge AR. Ros-mediated activation of NFkappaB and Foxo during muscle disuse. Muscle and Nerve 2010;41:110-3.

Dogra C, Changotra H, Wedhas N, Qin X, Wergedal JE, Kumar A. TNF-related weak inducer of apoptosis (TWEAK) is a potent skeletal muscle-wasting cytokine. FASEB Journal 2007;21:1857-69.

Donaldson GC, Wilkinson TM, Hurst JR, Perera WR, Wedzicha JA. Exacerbations and time spent outdoors in chronic obstructive pulmonary disease. American Journal of Respiratory and Critical Care Medicine 2005;171:446-52.

Doucet M, Russell AP, Leger B, Debigare R, Joanisse DR, Caron MA, et al. Muscle atrophy and hypertrophy signaling in patients with chronic obstructive pulmonary disease. American Journal of Respiratory and Critical Care Medicine 2007; 176:261-9.

Doyle A, Zhang G, Abdel Fattah EA, Eissa NT, Li YP. Toll-like receptor 4 mediates lipopolysaccharide-induced muscle catabolism via coordinate activation of ubiquitin-proteasome and autophagy-lysosome pathways. FASEB Journal 2011;25:99-110.

Du R, Chen YF, An XR, Yang XY, Ma Y, Zhang L, et al. Cloning and sequence analysis of myostatin promoter in sheep. DNA Sequence 2005;16:412-7.
Eid AA, Ionescu AA, Nixon LS, Lewis-Jenkins V, Matthews SB, Griffiths TL, et al. Inflammatory response and body composition in chronic obstructive pulmonary disease. American Journal of Respiratory and Critical Care Medicine 2001;164:1414-8.

Eliason G, Abdel-Halim S, Arvidsson B, Kadi F, Piehl-Aulin K. Physical performance and muscular characteristics in different stages of COPD. Scandinavian Journal of Medicine and Science in Sports 2009;19:865-70.

Engelen MP, Deutz NE, Wouters EF, Schols AM. Enhanced levels of whole-body protein turnover in patients with chronic obstructive pulmonary disease. American Journal of Respiratory and Critical Care Medicine 2000a;162 1488-92.

Engelen MP, Schols AM, Baken WC, Wesseling GJ, Wouters EF. Nutritional depletion in relation to respiratory and peripheral skeletal muscle function in out-patients with COPD. European Respiratory Journal 1994;7:1793-7.

Engelen MP, Schols AM, Lamers RJ, Wouters EF. Different patterns of chronic tissue wasting among patients with chronic obstructive pulmonary disease. Clinical Nutrition 1999;18:275-80.

Engelen MP, Wouters EF, Deutz NE, Menheere PP, Schols AM. Factors contributing to alterations in skeletal muscle and plasma amino acid profiles in patients with chronic obstructive pulmonary disease. American Journal of Clinical Nutrition 2000b;72:1480-7.

Favier FB, Costes F, Defour A, Bonnefoy R, Lefai E, Bauge S, et al. Downregulation of Akt/mammalian target of rapamycin pathway in skeletal muscle is associated with increased REDD1 expression in response to chronic hypoxia. American Journal of Physiology Regulatory, Integrative and Comparative Physiology 2010;298:R1659-66.

Fermoselle C, Rabinovich R, Ausin P, Puig-Vilanova E, Coronell C, Sanchez F, et al. Does oxidative stress modulate limb muscle atrophy in severe COPD patients? European Respiratory Journal 2012 [Epub ahead of print].

Ferreira IM, Brooks D, White J, Goldstein R. Nutritional supplementation for stable chronic obstructive pulmonary disease. Cochrane Database of Systematic Reviews 2012;12:CD000998.

Files DC, D'Alessio FR, Johnston LF, Kesari P, Aggarwal NR, Garibaldi BT, et al. A critical role for muscle ring finger-1 in acute lung injury-associated skeletal muscle wasting. American Journal of Respiratory and Critical Care Medicine 2012;185:825-34.

Gilson H, Schakman O, Combaret L, Lause P, Grobet L, Attaix D, et al. Myostatin gene deletion prevents glucocorticoid-induced muscle atrophy. Endocrinology 2007;148:452-60.

Glass DJ. Skeletal muscle hypertrophy and atrophy signaling pathways. International Journal of Biochemistry and Cell Biology 2005;37:1974-84.

Glover EI, Yasuda N, Tarnopolsky MA, Abadi A, Phillips SM. Little change in markers of protein breakdown and oxidative stress in humans in immobilizationinduced skeletal muscle atrophy. Applied Physiology, Nutrition, and Metabolism 2010;35:125-33.

Goodman MN, Lowell B, Belur E, Ruderman NB. Sites of protein conservation and loss during starvation: influence of adiposity. American Journal of Physiology 1984;246:E383-90

Gosker HR, Engelen MP, van Mameren H, van Dijk PJ, van der Vusse GJ, Wouters $\mathrm{EF}$, et al. Muscle fiber type IIX atrophy is involved in the loss of fat-free mass in chronic obstructive pulmonary disease. American Journal of Clinical Nutrition 2002;76:113-9.

Gosker HR, Kubat B, Schaart G, van der Vusse GJ, Wouters EF, Schols AM. Myopathological features in skeletal muscle of patients with chronic obstructive pulmonary disease. European Respiratory Journal 2003;22:280-5.

Gosker HR, Langen RC, Bracke KR, Joos GF, Brusselle GG, Steele C, et al. Extrapulmonary manifestations of chronic obstructive pulmonary disease in a mouse model of chronic cigarette smoke exposure. American Journal of Respiratory Cell and Molecular Biology 2009;40:710-6.

Guttridge DC, Mayo MW, Madrid LV, Wang CY, Baldwin AS Jr. NF-kappaB-induced loss of MyoD messenger RNA: possible role in muscle decay and cachexia. Science 2000;289:2363-6

Haegens A, Schols AM, van Essen AL, van Loon LJ, Langen RC. Leucine induces myofibrillar protein accretion in cultured skeletal muscle through mTOR dependent and -independent control of myosin heavy chain mRNA levels. Molecular Nutrition \& Food Research 2012;56:741-52

Hather BM, Adams GR, Tesch PA, Dudley GA. Skeletal muscle responses to lower limb suspension in humans. Journal of Applied Physics 1992;72:1493-8.

Hayot M, Rodriguez J, Vernus B, Carnac G, Jean E, Allen D, et al. Myostatin up regulation is associated with the skeletal muscle response to hypoxic stimuli. Molecular and Cellular Endocrinology 2011;332:38-47.

Hittel DS, Berggren JR, Shearer J, Boyle K, Houmard JA. Increased secretion and expression of myostatin in skeletal muscle from extremely obese women. Diabetes 2009:58:30-8.

Hopkinson NS, Tennant RC, Dayer MJ, Swallow EB, Hansel TT, Moxham J, et al. A prospective study of decline in fat free mass and skeletal muscle strength in chronic obstructive pulmonary disease. Respiratory Research 2007;8:25.

Hoppeler H, Kleinert E, Schlegel C, Claassen H, Howald H, Kayar SR, et al. Morphological adaptations of human skeletal muscle to chronic hypoxia. International Journal of Sports Medicine 1990;11(Suppl. 1):S3-9.

$\mathrm{Hu} \mathrm{Z}$, Wang $\mathrm{H}$, Lee IH, Du J, Mitch WE. Endogenous glucocorticoids and impaired insulin signaling are both required to stimulate muscle wasting under pathophysiological conditions in mice. Journal of Clinical Investigation 2009;119:3059-69.

Hussain SN, Sandri M. Role of autophagy in COPD skeletal muscle dysfunction. Journal of Applied Physics 2012;114:1273-81 
Jeanplong F, Bass JJ, Smith HK, Kirk SP, Kambadur R, Sharma M, et al. Prolonged underfeeding of sheep increases myostatin and myogenic regulatory factor Myf-5 in skeletal muscle while IGF-I and myogenin are repressed. Journal of Endocrinology 2003;176:425-37.

Jones SW, Hill RJ, Krasney PA, O'Conner B, Peirce N, Greenhaff PL. Disuse atrophy and exercise rehabilitation in humans profoundly affects the expression of genes associated with the regulation of skeletal muscle mass. FASEB Journal 2004;18:1025-7.

Ju CR, Chen RC. Serum myostatin levels and skeletal muscle wasting in chronic obstructive pulmonary disease. Respiratory Medicine 2012;106:102-8.

Kao CC, Hsu JW, Bandi V, Hanania NA, Kheradmand F, Jahoor F. Resting energy expenditure and protein turnover are increased in patients with severe chronic obstructive pulmonary disease. Metabolism: Clinical and Experimental 2011;60:1449-55.

Kollias HD, McDermott JC. Transforming growth factor-beta and myostatin signaling in skeletal muscle. Journal of Applied Physics 2008;104:579-87.

Koncarevic A, Jackman RW, Kandarian SC. The ubiquitin-protein ligase Nedd 4 targets Notch1 in skeletal muscle and distinguishes the subset of atrophies caused by reduced muscle tension. FASEB Journal 2007;21:427-37.

Kumari R, Willing LB, Jefferson LS, Simpson IA, Kimball SR. REDD1 (regulated in development and DNA damage response 1) expression in skeletal muscle as a surrogate biomarker of the efficiency of glucocorticoid receptor blockade. Biochemical and Biophysical Research Communications 2011;412:644-7.

Kuo T, Lew MJ, Mayba O, Harris CA, Speed TP, Wang JC. Genome-wide analysis of glucocorticoid receptor-binding sites in myotubes identifies gene networks modulating insulin signaling. Proceedings of the National Academy of Sciences of the United States of America 2012;109:11160-5.

Kythreotis P, Kokkini A, Avgeropoulou S, Hadjioannou A, Anastasakou E, Rasidakis A, et al. Plasma leptin and insulin-like growth factor I levels during acute exacerbations of chronic obstructive pulmonary disease. BMC Pulmonary Medicine 2009;9:11.

Langen RC, Haegens A, Vernooy JH, Wouters EF, de Winther MP, Carlsen H, et al. NF-kappa B activation is required for the transition of pulmonary inflammation to muscle atrophy. American Journal of Respiratory Cell and Molecular Biology 2012;47:288-97.

Langen RC, Schols AM, Kelders MC, van der Velden JL, Wouters EF, Janssen-Heininger YM. Muscle wasting and impaired muscle regeneration in a murine model of chronic pulmonary inflammation. American Journal of Respiratory Cell and Molecular Biology 2006:35:689-96.

Langen RC, Van Der Velden JL, Schols AM, Kelders MC, Wouters EF, Janssen-Heininger YM. Tumor necrosis factor-alpha inhibits myogenic differentiation through MyoD protein destabilization. FASEB Journal 2004;18:227-37.

Laplante M, Sabatini DM. mTOR signaling in growth control and disease. Cell 2012;149:274-93.

Lemire BB, Debigare R, Dube A, Theriault ME, Cote CH, Maltais F. Mapk signalling in the quadriceps of patients with chronic obstructive pulmonary disease. Journal of Applied Physiology 2012 [Epub ahead of print].

Lewis A, Riddoch-Contreras J, Natanek SA, Donaldson A, Man WD, Moxham J, et al. Downregulation of the serum response factor/miR-1 axis in the quadriceps of patients with COPD. Thorax 2011;67:26-34.

Lewis MI, Fournier M, Storer TW, Bhasin S, Porszasz J, Ren SG, et al. Skeletal muscle adaptations to testosterone and resistance training in men with COPD. Journal of Applied Physics 2007:103:1299-310.

Li YP, Reid MB. NF-kappaB mediates the protein loss induced by TNF-alpha in differentiated skeletal muscle myotubes. American Journal of Physiology Regulatory Integrative and Comparative Physiology 2000;279:R1165-70.

Liu L, Cash TP, Jones RG, Keith B, Thompson CB, Simon MC. Hypoxia-induced energy stress regulates mRNA translation and cell growth. Molecular Cell 2006;21:521-31.

MacDougall JD, Green HJ, Sutton JR, Coates G, Cymerman A, Young P, et al. Operation Everest II: structural adaptations in skeletal muscle in response to extreme simulated altitude. Acta Physiologica Scandinavica 1991;142:421-7.

MacLennan PA, Edwards RH. Effects of clenbuterol and propranolol on muscle mass. Evidence that clenbuterol stimulates muscle beta-adrenoceptors to induce hypertrophy. Biochemical Journal 1989;264:573-9.

Majmundar AJ, Skuli N, Mesquita RC, Kim MN, Yodh AG, Nguyen-McCarty M, et al. $\mathrm{O}_{2}$ regulates skeletal muscle progenitor differentiation through phosphatidylinositol 3-kinase/AKT signaling. Molecular and Cellular Biology 2012;32: 36-49.

Maltais F, LeBlanc P, Whittom F, Simard C, Marquis K, Belanger M, et al. Oxidative enzyme activities of the vastus lateralis muscle and the functional status in patients with COPD. Thorax 2000;55:848-53.

Man WD-C, Natanek SA, Riddoch-Contreras J, Lewis A, Marsh GS, Kemp PR, et al. Quadriceps myostatin expression in COPD. European Respiratory Journal 2010;36:686-8.

Man WD, Kemp P, Moxham J, Polkey MI. Exercise and muscle dysfunction in COPD: implications for pulmonary rehabilitation. Clinical Science (Lond) 2009;117:281-91.

Mancinelli R, Pietrangelo T, La Rovere R, Toniolo L, Fano G, Reggiani C, et al. Cellular and molecular responses of human skeletal muscle exposed to hypoxic environment. Journal of Biological Regulators and Homeostatic Agents 2011;25:635-45.

Mattson JP, Delp MD, Poole DC. Differential effects of emphysema on skeletal muscle fibre atrophy in hamsters. European Respiratory Journal 2004;23:703-7.

McFarlane C, Hui GZ, Amanda WZ, Lau HY, Lokireddy S, Xiaojia G, et al. Human myostatin negatively regulates human myoblast growth and differentiation. American Journal of Physiology Cell Physiology 2011;301:C195-203.
McGee SL, Hargreaves M. AMPK-mediated regulation of transcription in skeletal muscle. Clinical Science (Lond) 2010;118:507-18.

Menon MK, Houchen L, Singh SJ, Morgan MD, Bradding P, Steiner MC. Inflammatory and satellite cells in the quadriceps of patients with COPD and response to resistance training. Chest 2012;142:1134-42.

Mercken EM, Hageman GJ, Langen RC, Wouters EF, Schols AM. Decreased exerciseinduced expression of nuclear factor-kappaB-regulated genes in muscle of patients with COPD. Chest 2011;139:337-46.

Mizuno M, Savard GK, Areskog NH, Lundby C, Saltin B. Skeletal muscle adaptations to prolonged exposure to extreme altitude: a role of physical activity. High Altitude Medicine and Biology 2008;9:311-7.

Moldawer LL, Bistrian BR, Sobrado J, Blackburn GL. Muscle proteolysis in sepsis or trauma. New England Journal of Medicine 1983;309:494-5.

Morrison WL, Gibson JN, Scrimgeour C, Rennie MJ. Muscle wasting in emphysema. Clinical Science (Lond) 1988;75:415-20.

Mostert R, Goris A, Weling-Scheepers C, Wouters EF, Schols AM. Tissue depletion and health related quality of life in patients with chronic obstructive pulmonary disease. Respiratory Medicine 2000;94:859-67.

Murton AJ, Greenhaff PL. Physiological control of muscle mass in humans during resistance exercise, disuse and rehabilitation. Current Opinion in Clinical Nutrition and Metabolic Care 2010;13:249-54.

Nagpal P, Plant PJ, Correa J, Bain A, Takeda M, Kawabe H, et al. The ubiquitin ligase Nedd4-1 participates in denervation-induced skeletal muscle atrophy in mice. PLOS ONE 2012;7:e46427.

Nussbaumer-Ochsner Y, Rabe KF. Systemic manifestations of COPD. Chest 2011;139:165-73

Oudijk EJ, Gerritsen WB, Nijhuis EH, Kanters D, Maesen BL, Lammers JW, et al. Expression of priming-associated cellular markers on neutrophils during an exacerbation of COPD. Respiratory Medicine 2006;100:1791-9.

Oudijk EJ, Nijhuis EH, Zwank MD, van de Graaf EA, Mager HJ, Coffer PJ, et al. Systemic inflammation in COPD visualised by gene profiling in peripheral blood neutrophils. Thorax 2005;60:538-44.

Pansters NA, Langen RC, Wouters E, Schols AM. Synergistic stimulation of myogenesis by glucocorticoid and IGF-I signaling. Journal of Applied Physics 2012;114:1329-39.

Pereira C, Murphy K, Jeschke M, Herndon DN. Post burn muscle wasting and the effects of treatments. International Journal of Biochemistry and Cell Biology 2005;37:1948-61.

Piehl-Aulin K, Jones I, Lindvall B, Magnuson A, Abdel-Halim SM. Increased serum inflammatory markers in the absence of clinical and skeletal muscle inflammation in patients with chronic obstructive pulmonary disease. Respiration 2009; 78:191-6.

Pitta F, Troosters T, Probst VS, Spruit MA, Decramer M, Gosselink R. Physical activity and hospitalization for exacerbation of COPD. Chest 2006;129:536-44.

Plant PJ, Brooks D, Faughnan M, Bayley T, Bain J, Singer L, et al. Cellular markers of muscle atrophy in chronic obstructive pulmonary disease. American Journal of Respiratory Cell and Molecular Biology 2010;42:461-71.

Powers SK, Smuder AJ, Judge AR. Oxidative stress and disuse muscle atrophy: cause or consequence. Current Opinion in Clinical Nutrition and Metabolic Care 2012;15:240-5

Qin W, Pan J, Wu Y, Bauman WA, Cardozo C. Protection against dexamethasoneinduced muscle atrophy is related to modulation by testosterone of FOXO1 and PGC-1alpha. Biochemical and Biophysical Research Communications 2010;403:473-8.

Raff H, Levy SA. Renin-angiotensin II-aldosterone and ACTH-cortisol control during acute hypoxemia and exercise in patients with chronic obstructive pulmonary disease. American Review of Respiratory Disease 1986;133:396-9.

Razeghi P, Baskin KK, Sharma S, Young ME, Stepkowski S, Essop MF, et al. Atrophy, hypertrophy, and hypoxemia induce transcriptional regulators of the ubiquitin proteasome system in the rat heart. Biochemical and Biophysical Research Communications 2006;342:361-4.

Remels AH, Gosker HR, Langen RC, Schols AM. The mechanisms of cachexia underlying muscle dysfunction in COPD. Journal of Applied Physics 2012;114:1253-62.

Ren H, Accili D, Duan C. Hypoxia converts the myogenic action of insulin-like growth factors into mitogenic action by differentially regulating multiple signaling pathways. Proceedings of the National Academy of Sciences of the United States of America 2010:107:5857-62.

Riddoch-Contreras J, George T, Natanek SA, Marsh GS, Hopkinson NS, Tal-Singer R, et al. p38 mitogen-activated protein kinase is not activated in the quadriceps of patients with stable chronic obstructive pulmonary disease. Journal of Chronic Obstructive Pulmonary Disease 2012;9:142-50.

Riva C, Chevrier C, Pasqual N, Saks V, Rossi A. Bcl-2/Bax protein expression in heart, slow-twitch and fast-twitch muscles in young rats growing under chronic hypoxia conditions. Molecular and Cellular Biochemistry 2001;226:9-16.

Romme EA, Murchison JT, Phang KF, Jansen FH, Rutten EP, Wouters EF, et al. Bone attenuation on routine chest CT correlates with bone mineral density on DXA in patients with COPD. Journal of Bone and Mineral Research 2012;27:2338-43.

Rommel C, Bodine SC, Clarke BA, Rossman R, Nunez L, Stitt TN, et al. Mediation of IGF-1-induced skeletal myotube hypertrophy by PI(3)K/Akt/mTOR and $\mathrm{PI}(3) \mathrm{K} /$ Akt/GSK3 pathways. Nature Cell Biology 2001;3:1009-13.

Rouschop KM, Wouters BG. Regulation of autophagy through multiple independent hypoxic signaling pathways. Current Molecular Medicine 2009;9:417-24

Rutten EP, Franssen FM, Engelen MP, Wouters EF, Deutz NE, Schols AM Greater whole-body myofibrillar protein breakdown in cachectic patients with chronic obstructive pulmonary disease. American Journal of Clinical Nutrition 2006;83:829-34. 
Sandri M, Sandri C, Gilbert A, Skurk C, Calabria E, Picard A, et al. Foxo transcription factors induce the atrophy-related ubiquitin ligase atrogin-1 and cause skeletal muscle atrophy. Cell 2004;117:399-412.

Schakman O, Gilson H, de Coninck V, Lause P, Verniers J, Havaux X, et al. Insulinlike growth factor-I gene transfer by electroporation prevents skeletal muscle atrophy in glucocorticoid-treated rats. Endocrinology 2005;146:1789-97.

Schakman O, Kalista S, Bertrand L, Lause P, Verniers J, Ketelslegers JM, et al. Role of Akt/GSK-3beta/beta-catenin transduction pathway in the muscle anti-atrophy action of insulin-like growth factor-I in glucocorticoid-treated rats. Endocrinology 2008;149:3900-8.

Schols AM, Broekhuizen R, Weling-Scheepers CA, Wouters EF. Body composition and mortality in chronic obstructive pulmonary disease. American Journal of Clinical Nutrition 2005;82:53-9.

Schols AM, Creutzberg EC, Buurman WA, Campfield LA, Saris WH, Wouters EF. Plasma leptin is related to proinflammatory status and dietary intake in patients with chronic obstructive pulmonary disease. American Journal of Respiratory and Critical Care Medicine 1999;160:1220-6.

Schols AM, Soeters PB, Dingemans AM, Mostert R, Frantzen PJ, Wouters EF. Prevalence and characteristics of nutritional depletion in patients with stable COPD eligible for pulmonary rehabilitation. American Review of Respiratory Disease 1993; $147: 1151-6$

Schols AM, Soeters PB, Mostert R, Pluymers RJ, Wouters EF. Physiologic effects of nutritional support and anabolic steroids in patients with chronic obstructive pulmonary disease. A placebo-controlled randomized trial. American Journal of Respiratory and Critical Care Medicine 1995:152:1268-74.

Schols AM, Wesseling G, Kester AD, de Vries G, Mostert R, Slangen J, et al. Dose dependent increased mortality risk in COPD patients treated with oral glucocorticoids. European Respiratory Journal 2001;17:337-42.

Senf SM, Dodd SL, Judge AR. FOXO signaling is required for disuse muscle atrophy and is directly regulated by Hsp70. American Journal of Physiology Cell Physiology 2010;298:C38-45.

Shah OJ, Anthony JC, Kimball SR, Jefferson LS. 4E-BP1 and S6K1: translational integration sites for nutritional and hormonal information in muscle. American Journal of Physiology - Endocrinology and Metabolism 2000;279:E715-29.

Shavlakadze T, Winn N, Rosenthal N, Grounds MD. Reconciling data from transgenic mice that overexpress IGF-I specifically in skeletal muscle. Growth Hormone and IGF Research 2005;15:4-18.

Shimizu N, Yoshikawa N, Ito N, Maruyama T, Suzuki Y, Takeda S, et al. Crosstalk between glucocorticoid receptor and nutritional sensor mTOR in skeletal muscle. Cell Metabolism 2011;13:170-82.

Shrikrishna D, Patel M, Tanner RJ, Seymour JM, Connolly BA, Puthucheary ZA, et al. Quadriceps wasting and physical inactivity in patients with COPD. European Respiratory Journal 2012;40:1115-22.

Snijders T, Verdijk LB, Beelen M, McKay BR, Parise G, Kadi F, et al. A single bout of exercise activates skeletal muscle satellite cells during subsequent overnight recovery. Experimental Physiology 2012;97:762-73.

Soler-Cataluna JJ, Martinez-Garcia MA, Roman Sanchez P, Salcedo E, Navarro M, Ochando R. Severe acute exacerbations and mortality in patients with chronic obstructive pulmonary disease. Thorax 2005;60:925-31.

Stevenson CS, Birrell MA. Moving towards a new generation of animal models for asthma and COPD with improved clinical relevance. Pharmacology \& Therapeutics 2011;130:93-105.

Stitt TN, Drujan D, Clarke BA, Panaro F, Timofeyva Y, Kline WO, et al. The IGF-1/PI3K/Akt pathway prevents expression of muscle atrophy-induced ubiquitin ligases by inhibiting FOXO transcription factors. Molecular Cell 2004; 14:395-403.

Suetta C, Frandsen U, Jensen L, Jensen MM, Jespersen JG, Hvid LG, et al. Aging affects the transcriptional regulation of human skeletal muscle disuse atrophy. PLOS ONE 2012;7:e51238

Takabatake N, Nakamura H, Abe S, Inoue S, Hino T, Saito H, et al. The relationship between chronic hypoxemia and activation of the tumor necrosis factor-alpha system in patients with chronic obstructive pulmonary disease. American Journal of Respiratory and Critical Care Medicine 2000;161:1179-84.

Takabatake N, Nakamura H, Minamihaba O, Inage M, Inoue S, Kagaya S, et al. A novel pathophysiologic phenomenon in cachexic patients with chronic obstructive pulmonary disease: the relationship between the circadian rhythm of circulating leptin and the very low-frequency component of heart rate variability. American Journal of Respiratory and Critical Care Medicine 2001;163:1314-9.

Tanabe N, Muro S, Hirai T, Oguma T, Terada K, Marumo S, et al. Impact of exacerbations on emphysema progression in chronic obstructive pulmonary disease. American Journal of Respiratory and Critical Care Medicine 2011;183:1653-9.

Tang H, Pang S, Wang M, Xiao X, Rong Y, Wang H, et al. TLR4 activation is required for IL-17-induced multiple tissue inflammation and wasting in mice. Journal of Immunology 2010a;185:2563-9.

Tang K, Wagner PD, Breen EC. TNF-alpha-mediated reduction in PGC-1alpha may impair skeletal muscle function after cigarette smoke exposure. Journal of Cellular Physiology 2010b;222:320-7

Tashkin DP, Celli B, Senn S, Burkhart D, Kesten S, Menjoge S, et al. A 4-year trial of tiotropium in chronic obstructive pulmonary disease. New England Journal of Medicine 2008;359:1543-54.

Tesch PA, von Walden F, Gustafsson T, Linnehan RM, Trappe TA. Skeletal muscle proteolysis in response to short-term unloading in humans. Journal of Applied Physics 2008;105:902-6.

Theriault ME, Pare ME, Maltais F, Debigare R. Satellite cells senescence in limb muscle of severe patients with COPD. PLOS ONE 2012;7:e39124.
Tracey KJ, Wei H, Manogue KR, Fong Y, Hesse DG, Nguyen HT, et al. Cachectin/tumor necrosis factor induces cachexia, anemia, and inflammation. Journal of Experimental Medicine 1988;167:1211-27.

Trendelenburg AU, Meyer A, Rohner D, Boyle J, Hatakeyama S, Glass DJ. Myostatin reduces Akt/TORC1/p70S6K signaling, inhibiting myoblast differentiation and myotube size. American Journal of Physiology Cell Physiology 2009;296:C1258-70.

Troosters T, Probst VS, Crul T, Pitta F, Gayan-Ramirez G, Decramer M, et al. Resistance training prevents deterioration in quadriceps muscle function during acute exacerbations of chronic obstructive pulmonary disease. American Journal of Respiratory and Critical Care Medicine 2010;181:1072-7.

Turan N, Kalko S, Stincone A, Clarke K, Sabah A, Howlett K, et al. A systems biology approach identifies molecular networks defining skeletal muscle abnormalities in chronic obstructive pulmonary disease. PLOS Computational Biology 2011;7:e1002129.

Ubhi BK, Riley JH, Shaw PA, Lomas DA, Tal-Singer R, Macnee W, et al. Metabolic profiling detects biomarkers of protein degradation in COPD patients. European Respiratory Journal 2011 [Epub ahead of print].

Urbani L, Piccoli M, Franzin C, Pozzobon M, De Coppi P. Hypoxia increases mouse satellite cell clone proliferation maintaining both in vitro and in vivo heterogeneity and myogenic potential. PLOS ONE 2012;7:e49860.

van den Borst B, Gosker HR, Koster A, Yu B, Kritchevsky SB, Liu Y, et al. The influence of abdominal visceral fat on inflammatory pathways and mortality risk in obstructive lung disease. American Journal of Clinical Nutrition 2012;96:516-26.

Van Gammeren D, Damrauer JS, Jackman RW, Kandarian SC. The IkappaB kinases IKKalpha and IKKbeta are necessary and sufficient for skeletal muscle atrophy. FASEB Journal 2009;23:362-70.

van Helvoort HA, Heijdra YF, Thijs HM, Vina J, Wanten GJ, Dekhuijzen PN. Exerciseinduced systemic effects in muscle-wasted patients with COPD. Medicine and Science in Sports and Exercise 2006;38:1543-52.

Verhees KJ, Schols AM, Kelders MC, Op den Kamp CM, van der Velden JL, Langen RC. Glycogen synthase kinase-3beta is required for the induction of skeletal muscle atrophy. American Journal of Physiology Cell Physiology 2011;301: C995-1007

Vermeeren MA, Schols AM, Wouters EF. Effects of an acute exacerbation on nutritional and metabolic profile of patients with COPD. European Respiratory Journal 1997; 10:2264-9

Vernooy JH, Kucukaycan M, Jacobs JA, Chavannes NH, Buurman WA, Dentener MA, et al. Local and systemic inflammation in patients with chronic obstructive pulmonary disease: soluble tumor necrosis factor receptors are increased in sputum. American Journal of Respiratory and Critical Care Medicine 2002;166:1218-24

Vestbo J, Hurd SS, Agusti AG, Jones PW, Vogelmeier C, Anzueto A, et al. Globa strategy for the diagnosis, management, and prevention of chronic obstructive pulmonary disease: GOLD executive summary. American Journal of Respiratory and Critical Care Medicine 2013;187:347-65.

Vestbo J, Prescott E, Almdal T, Dahl M, Nordestgaard BG, Andersen T, et al. Body mass, fat-free body mass, and prognosis in patients with chronic obstructive pulmonary disease from a random population sample: findings from the Copenhagen City Heart Study. American Journal of Respiratory and Critical Care Medicine 2006;173:79-83.

Vogiatzis I, Simoes DC, Stratakos G, Kourepini E, Terzis G, Manta P, et al. Effect of pulmonary rehabilitation on muscle remodelling in cachectic patients with COPD. European Respiratory Journal 2010;36:301-10.

Vogiatzis I, Stratakos G, Simoes DC, Terzis G, Georgiadou O, Roussos C, et al. Effects of rehabilitative exercise on peripheral muscle TNFalpha, IL-6, IGF-I and MyoD expression in patients with COPD. Thorax 2007;62:950-6.

Vorrink SN, Kort HS, Troosters T, Lammers JW. Level of daily physical activity in individuals with COPD compared with healthy controls. Respiratory Research 2011;12:33.

Waddell DS, Baehr LM, van den Brandt J, Johnsen SA, Reichardt HM, Furlow JD, et al. The glucocorticoid receptor and FOXO1 synergistically activate the skeletal muscle atrophy-associated MuRF1 gene. American Journal of Physiology Endocrinology and Metabolism 2008;295:E785-97.

Westerterp-Plantenga MS, Westerterp KR, Rubbens M, Verwegen CR, Richelet JP, Gardette B. Appetite at high altitude [Operation Everest III (Comex-'97)]: a simulated ascent of Mount Everest. Journal of Applied Physics 1999;87:391-9.

Williamson DL, Kimball SR, Jefferson LS. Acute treatment with TNF-alpha attenuates insulin-stimulated protein synthesis in cultures of C2C12 myotubes through a MEK1-sensitive mechanism. American Journal of Physiology - Endocrinology and Metabolism 2005;289:E95-104

Wing SS, Goldberg AL. Glucocorticoids activate the ATP-ubiquitin-dependent proteolytic system in skeletal muscle during fasting. American Journal of Physiology 1993;264:E668-76.

Witard OC, Tieland M, Beelen M, Tipton KD, van Loon LJ, Koopman R. Resistance exercise increases postprandial muscle protein synthesis in humans. Medicine and Science in Sports and Exercise 2009;41:144-54

Wouters BG, Koritzinsky M. Hypoxia signalling through mTOR and the unfolded protein response in cancer. Nature Reviews Cancer 2008;8:851-64.

Wouters EF, Groenewegen KH, Dentener MA, Vernooy JH. Systemic inflammation in chronic obstructive pulmonary disease: the role of exacerbations. Proceedings of the American Thoracic Society 2007;4:626-34.

Wu CL, Kandarian SC, Jackman RW. Identification of genes that elicit disuse mus cle atrophy via the transcription factors p50 and Bcl-3. PLOS ONE 2011;6: e16171. 